\title{
Property Rules vs. Liability Rules for Patent Infringement *
}

\author{
Carl Shapiro ${ }^{\dagger}$ \\ University of California at Berkeley \\ 10 January 2017
}

\begin{abstract}
When a patent has been infringed, the court can impose a forward-looking remedy based on a property rule or based on a liability rule. Under the property rule, the court issues an injunction ordering the infringing party to stop infringing. Under the liability rule, the court allows the infringing party to continue to infringe the patent in question so long as it pays specified ongoing royalties to the patent holder. Since the Supreme Court's landmark 2006 decision in the eBay case, the United States has employed a hybrid system: the lower courts have discretion, on a case-by-case basis, to issue an injunction or to establish ongoing royalties. This article develops a simple model, including the possibility of patent holdup, in which the court has an imperfect ability to measure the harm to the patent holder caused by ongoing infringement. In the model, the patent holder and the infringing firm can negotiate efficiently over a patent license following the court's imposition of a remedy, possibly subject to antitrust limits. Following patent law, remedy regimes are evaluated based on how close they come to compensating the patent holder for any ongoing infringement. The model identifies a fundamental tradeoff: ongoing royalties set based on the court's best point estimate perform better, the greater are the switching costs the infringing firm would bear to redesign its product to avoid infringing, but an injunction performs better, the greater is the court's uncertainty about the harm that ongoing infringement will cause to the patent holder. The optimal level of ongoing royalties is also studied. Based on this analysis, recommendations regarding prospective patent remedies are offered to the courts.
\end{abstract}

\footnotetext{
* I thank Jorge Contreras, Aaron Edlin, Joe Farrell, Richard Gilbert, Louis Kaplow, Doug Melamed, Steve Salop, Fiona Scott Morton, Christopher Seaman, Tim Simcoe, Jean Tirole, Abe Wickelgren, various seminar participants, and the referees and editor for very helpful input. Please send any comments to cshapiro@berkeley.edu. This paper is available at http://faculty.haas.berkeley.edu/shapiro/propvsliab.pdf.

${ }^{\dagger}$ Transamerica Professor of Business Strategy at the Haas School of Business at the University of California at Berkeley. No party other than UC Berkeley provided any financial support for this paper.
} 


\section{Introduction}

This paper compares the performance of permanent injunctions and ongoing royalties as forward-looking remedies in patent infringement cases. We also study how ongoing royalties should be set when they are used by the courts.

Until about ten years ago, the remedies available in the United States to a patent holder whose patent had been found valid and infringed were clear: the patent holder would be compensated for past infringement by an award of patent damages, and the court would issue an injunction preventing the infringing party from continuing to infringe the patent in question. But the treatment of forward-looking patent remedies changed dramatically as a result of the 2006 decision by the Supreme Court in the eBay case. In that case, the Supreme Court stated:

"According to well-established principles of equity, a plaintiff seeking a permanent injunction must satisfy a four-factor test before a court may grant such relief. A plaintiff must demonstrate: (1) that it has suffered an irreparable injury; (2) that remedies available at law, such as monetary damages, are inadequate to compensate for that injury; (3) that, considering the balance of hardships between the plaintiff and defendant, a remedy in equity is warranted; and (4) that the public interest would not be disserved by a permanent injunction."1

Justice Kennedy's concurrence in the $e B a y$ case explicitly recognized that injunctions could greatly over-reward patent holders in situations where the infringing party had made substantial specific investments to develop the infringing product.

\footnotetext{
"When the patented invention is but a small component of the product the companies seek to produce and the threat of an injunction is employed simply for undue leverage in negotiations, legal damages may well be sufficient to compensate for the infringement and an injunction may not serve the public interest. ${ }^{2}$
}

In the language of transaction-cost economics, injunctions can allow patent holders to engage in holdup based on specific investments made by downstream firms. Shapiro (2010) shows that the danger of patent holdup is especially great in situations where (a) the patented technology covers a feature that adds relatively little value to the infringing product, yet (b) redesigning the product to avoid infringing is costly or time-consuming. The Federal Trade Commission has emphasized that patent holdup can retard innovation and harm consumers. ${ }^{3}$

The court's choice between an injunction and ongoing royalties involves a fundamental tradeoff. By imposing an injunction, the court can ensure that the patent holder will not be harmed by ongoing infringement, since no such infringement can occur without the patent holder's agreement. However, if the infringing firm has made investments specific to the patented

\footnotetext{
1 eBay Inc. v. MercExchange, L.L.C. , 547 U.S. 388 (2006), at 390.

2 eBay, 547 U.S. 388 at 396-7 (concurring opinion by Justice Kennedy). More recently, the Federal Circuit has explicitly recognized the danger of patent holdup. "Patent hold-up exists when the holder of a SEP [standardessential patent] demands excessive royalties after companies are locked into using a standard." See Ericsson Inc. v. D-Link Systems, 773 F.3d. 1201 (2014), at 1209.

3 "Under some circumstances, however, the threat of an injunction can lead an infringer to pay higher royalties than the patentee could have obtained in a competitive technology market. At the time a manufacturer faces an infringement allegation, switching to an alternative technology may be very expensive if it has sunk costs in production using the patented technology. ... Patent hold-up can overcompensate patentees, raise prices to consumers who lose the benefits of competition among technologies, and deter innovation by manufacturers facing the risk of hold-up." Federal Trade Commission (2011), Introduction, p. 5.
} 
technology, an injunction can greatly over-reward the patent holder by enabling patent holdup. In contrast, while a remedy based on ongoing royalties can prevent patent holdup, setting the ongoing royalties based on the Court's best point estimate also can under-reward the patent holder. The model developed below explores this tradeoff in depth.

There is a long and rich literature on property rules vs. liability rules, beginning with the seminal paper by Calabresi and Melamed (1972). Building on Coase (1960), Calabresi and Melamed construct a framework for studying how different legal rules affect economic efficiency in the presence of transaction costs and apply that framework to pollution control rules and criminal sanctions. The current paper is closest to Kaplow and Shavell (1996a), who build a formal model to compare the performance of property vs. liability rules.

Kaplow and Shavell analyze "the taking of things." They use ex post efficiency as their objective function, without regard to how the total value created is split between the two parties, the "owner" and the "taker." In their model, if the parties bargain efficiently, the property and liability rules are equivalent. ${ }^{4}$ They therefore focus on situations in which ex post bargaining is not efficient. ${ }^{5}$ In the current paper, we take a fundamentally different approach. We assume that ex post bargaining between the patent holder and the infringing firm is efficient and focus on the ex ante incentives created by different remedy regimes. More specifically, following patent law, the objective here is to accurately compensate the patent holder for any infringement. The property and liability rules are very different in this respect, since the property rule generally puts the patent holder in a more favorable position in the ex post negotiations over a patent license.

The model developed here is quite distinct from previous economic models relating to patent damages for past infringement. Schankerman and Scotchmer (2001) compare damages based on lost profits with damages based on unjust enrichment. Their analysis focuses on cases where the patent covers a proprietary research tool, so there are gains from trade from ex ante licensing. In their model, the courts have perfect information and there is no infringement in equilibrium: patent damages establish the threat point for ex ante bargaining. The model here, by contrast, applies to situations in which the courts have imperfect information and ex ante licensing often is not feasible. Anton and Yao (2007) study damages based on lost profits in situations where the infringement leads to a duopoly and the infringing firm behaves strategically, so the patent holder's lost profits are endogenous. Their model does not include patent holdup or imperfect information by the court regarding the harm to the patent holder caused by the infringement.

Section 2 provides a brief background on patent remedies law. Section 3 introduces our model. Following patent law, we assume that the court's objective is to compensate the patent holder for any ongoing infringement. Section 4 analyzes the ex post bargaining between the patent holder and the infringing firm after the court issues an injunction or establishes ongoing royalties. Section 5 presents our main results. Section 6 presents additional results that apply if the patent

\footnotetext{
${ }^{4}$ Kaplow and Shavell (1996a), p. 764.

${ }^{5}$ Kaplow and Shavell consider situations in which the parties cannot bargain with each other (p. 759-763) and situations in which the bargaining is not always successful (p. 764-765). In the latter case, they state (p. 764) that "the problem of failure to conclude mutually beneficial bargains might be either more or less serious under property rule protection than under the liability rule. Thus, it may be that either rule is better (as was true in the case of externalities). Still, we suspect that property rule protection will tend to be superior to the liability rule." They have in mind situations in which the owner generally values the object more than the taker. In contrast, in most patent infringement cases there are gains from trade when the infringing firm uses the patented technology.
} 
holder's compensation takes the form of reasonable royalties. Section 7 discusses the firms' incentives to innovate and to engage in ex ante licensing. Section 8 discusses the implications of our results for courts choosing a prospective remedy for patent infringement. Section 9 discusses two creative and possibly superior prospective remedy regimes.

\section{Patent Remedies: Brief Legal Background}

This section provides some background information regarding patent remedies law. ${ }^{6}$

\section{A. Compensating the Patent Holder for Any Infringement}

Patent infringement cases typically arise when a patent holder sues another firm for selling products that use the patented technology. If the court finds the patent to be valid and infringed, the patent holder is entitled to compensatory damages. The Patent Act states:

"Upon finding for the claimant the court shall award the claimant damages adequate to compensate for the infringement, but in no event less than a reasonable royalty for the use made of the invention by the infringer, together with interest and costs as fixed by the court."7

If the patent holder competes against the infringing firm, damages are typically calculated based on the patent holder's lost profits. If not, they are usually based on reasonable royalties. ${ }^{8}$ Reasonable royalties are the royalties that would result from a "hypothetical negotiation" between the patent holder and the infringing firm taking place before the infringement started. ${ }^{9}$ From 2006 to 2015, damages based on reasonable royalties were awarded in $79 \%$ of the patent infringement cases involving damages, while damages based on lost profits were awarded in $39 \%$ of these cases. ${ }^{10}$ The median damages award during 2011-2015 was $\$ 9.2$ million. ${ }^{11}$

As indicated by the Supreme Court in the $e B a y$ case, the goal of the prospective remedy, much like the goal of damages for past infringement, is to compensate the patent holder for any infringement. $^{12}$ The Federal Circuit Court of Appeals has followed this approach since eBay.

The analysis in this article follows patent law and takes as given that the basic goal of the patent remedy regime is to compensate the patent holder for any infringement that takes place. Given this goal, patent remedies are evaluated based on how close them come to properly compensating patent owners for infringement on an ex ante basis. Under-compensation is undesirable because it undermines the central goal of the patent system, which is to reward innovators who receive patents. Over-compensation also is undesirable because it increases the deadweight losses

\footnotetext{
${ }^{6}$ For extensive treatments, see Cotter (2013) and Cotter and Golden (2015).

${ }^{7} 35$ U.S. Code $\S 284$.

${ }^{8}$ See, for example, Cotter (2013) and Contreras and Gilbert (2015).

${ }^{9}$ See, for example Rite-Hite Corp. v. Kelley Co., 56 F.3d 1538 (1995) (Federal Circuit).

${ }^{10}$ See PWC (2016), Figure 7, p.6. 18\% of the cases involved both lost profits and reasonable royalties.

${ }^{11}$ See PWC (2016), Figure 5b, p.4. This figure excludes summary and default judgments. The median award to non-practicing entities was $\$ 13.3$ million, while the median award to practicing entities was $\$ 4.9$ million. See Figure 12, p.10.

${ }^{12}$ See also Paice v. Toyota 504 F. 3d 1293 (2007) at 1315.
} 
associated with the patent system and discourages innovations that are complementary to patented inventions.

The analysis in this article does not attempt to determine the optimal prospective remedy for patent infringement based on a compete welfare analysis, for three reasons. First, our aim here is to be quite practical and to generate useful guidance for the courts. The courts are obliged to follow the Supreme Court's guidance in the eBay case and award either an injunction or ongoing royalties with the goal of properly compensating the patent owner for infringement. Second, we know that the optimal remedy based on a complete welfare analysis depends critically on (1) the elasticity of supply of inventions with respect to the size of the remedy, (2) the magnitude of the spillovers associated with these inventions, (3) the elasticity of supply of new products that may later be judged to infringe some patent with respect to the size of the remedy, (4) the magnitude of the spillovers associated with those new products. None of these variables is amenable to empirical estimation, either in general or in specific cases, so it is hard to see how the results coming out of such a welfare analysis would be of practical use to the courts. Third, when considering innovation incentives, one must view the patent system as a whole, including patent length and many other aspects of the system, such as the presumption of validity afforded to patent holders when they sue for infringement. Remedies for patent infringement are a part of that overall system, and within that system remedies are intended to compensate the patent holder for infringement, no more and no less. ${ }^{13}$ Section 7 explains the relationship between the analysis here and a complete welfare analysis of prospective patent remedies.

Even without a formal model of firms' R\&D decisions, it is clear that the current legal treatment of patent remedies, which is based on fully compensating patent holders for any infringement, by design preserves the basic incentive to innovate that underlies the patent system.

\section{B. Enhanced Damages to Deter Infringement}

This article focuses on remedies in situations where the court has found that the defendant has infringed a valid patent. One's attitude toward such situations is naturally colored by the conduct that led up to the court's finding of infringement. Compare these two distinct fact patterns:

- "Guilty" Infringement: the defendant copied the patented technology from the patent holder rather than seeking a patent license, or after being denied a license.

- "Innocent" Infringement: the defendant developed its product independently, unaware of the patent, and the patented technology covers one feature of the defendant's product.

In cases of "guilty" infringement, the courts can award enhanced damages. Enhanced damages can be up to three times as large as the compensatory damages. Enhanced damages are intended to deter "willful infringement." According to the Supreme Court: "Consistent with nearly two centuries of enhanced damages under patent law, however, such punishment should generally be reserved for egregious cases typified by willful misconduct." ${ }^{\prime 4}$ The current article studies compensatory damages and does not address enhanced damages.

Lee and Melamed (2016) explain that most infringement in the high-tech sector would be very difficult and even inefficient to avoid due to the large number of patents that can read on a single

\footnotetext{
${ }^{13}$ Enhanced damages are the exception to this statement. They are discussed immediately below.

${ }^{14}$ See Halo Electronics v. Pulse Electronics, 136 S. Ct. 1923 (2016) at 1934.
} 
product, the vague boundaries of those patents, and the fact that many patents are found invalid when tested in court. ${ }^{15}$ RPX has estimated that more than 250,000 active patents are relevant to today's smartphones. ${ }^{16}$ Cotropia and Lemley (2009) show that only a small share of patent cases involving copying. The model developed in this article is primarily intended to apply to "innocent" infringement, to which enhanced damages do not apply. ${ }^{17}$ Such "innocent" infringement is common in the high-tech sector.

Even without enhanced damages, current U.S. patent law provides a strong incentive for a firm developing a new product to avoid infringing an existing patent, either by designing around the patent or obtaining a patent license, according to the general principle in law and economics that damages paid by a liable party should equal the harm caused by that party. ${ }^{18}$ See Section 7.A for a further discussion of the incentives of the patent holder and the downstream firm to negotiate a patent license before any infringement takes place.

\section{Injunctions vs. Ongoing Royalties Since eBay}

In the ten years since the Supreme Court's decision in the $e B a y$ case, the Federal Circuit has developed a body of law guiding the lower courts regarding the decision to grant an injunction or award ongoing royalties. As a starting point, the Federal Circuit has stated that the patent holder must satisfy all four $e$ Bay factors to qualify for an injunction. ${ }^{19}$ However, Cotter (2013, p. 102) observes that "the four-factor test purports to distinguish two factors, irreparable harm and no adequate remedy at law, that are functionally identical." Likewise, Gergen, et. al. (2012) point out that irreparable harm and the inadequacy of monetary damages are very difficult to distinguish, and the FTC $(2011$, p. 228) reports that "courts and commentators often analyze the first two eBay factors as one."

Regarding irreparable harm and the adequacy of monetary damages, the courts tend to focus on whether they can accurately assess the harm that is involved. When the future harm is based on loss of market share or reputation and good will, the Federal Circuit typically considers that harm to be very difficult to measure accurately and thus "irreparable." 20 Seaman (2016, Figure 4)

\footnotetext{
${ }^{15}$ Lee and Melamed (2016, p. 46) state "we call an infringer 'innocent' if it could not cost-efficiently have negotiated a license ex ante." See also Shapiro (2000), FTC (2011). Menell and Meurer (2013) discuss the problem of "notice failure" and "the distinctive pathology of notice externalities" in the development of intangible resources.

${ }^{16}$ RPX S-1 Form 2011, at p. 59. Patent owners themselves object to a requirement that they disclose all of their patents that are essential to a proposed standard on the ground that identifying these patents is highly burdensome.

${ }^{17}$ Enhanced damages are a separate instrument that provides incentives for firms developing new products to search for patents that they might infringe and clear their products in advance.

${ }^{18}$ For a recent, succinct demonstration of this principle see Polinsky and Shavell (2014), who show how to modify this general principle to account for litigation costs. Additional compensation is desirable if liability is difficult for the injured party to detect; enhanced damages serve a deterrence function in such cases.

19 "Not all patentees will be able to show injury, and even those who do must still satisfy the other three factors." $i 4 i$ v. Microsoft 598 F. 3d 831 at 862 (2010).

${ }^{20}$ In $i 4 i$ v. Microsoft 598 F. 3d 831 at 862, the Federal Circuit states: "In this case, a small company was practicing its patent, only to suffer a loss of market share, brand recognition, and customer goodwill as the result of the defendant's infringing acts. Such losses may frequently defy attempts at valuation, particularly when the infringing acts significantly change the relevant market, as occurred here. The district court found that Microsoft captured $80 \%$ of the custom XML market with its infringing Word products, forcing i4i to change its business strategy. The loss associated with these effects is particularly difficult to quantify. Difficulty in estimating monetary damages is
} 
reports that patent holders' requests for permanent injunctions from 2006 to 2013 were granted in $84 \%$ of the cases where the patent holder and the infringing firm were competitors. In contrast, when the harm comes in the form of lost licensing revenues, the Federal Circuit is far more likely to view monetary damages as adequate. ${ }^{21}$ Seaman (2016, Figure 4) reports that patent holders' requests for permanent injunctions were granted in only $21 \%$ of the cases the patent holder and the infringing firm were not competitors.

The Federal Circuit has not explicitly embraced the view that high switching costs, and thus the prospect of patent holdup, can provide the basis for denying an injunction based on the balancing of harms. As noted above, the Federal Circuit recognizes the danger of patent holdup, but they also have made this statement regarding the eBay test:

\begin{abstract}
"The district court's analysis properly ignored the expenses Microsoft incurred in creating the infringing products. See Acumed, 551 F.3d at 1330. Similarly irrelevant are the consequences to Microsoft of its infringement, such as the cost of redesigning the infringing products. Id. As we explained in Broadcom, neither commercial success, nor sunk development costs, shield an infringer from injunctive relief. Microsoft is not entitled to continue infringing simply because it successfully exploited its infringement.",22
\end{abstract}

This approach to prospective remedies is highly problematic given the eBay decision and is not supported by the analysis provided here.

\title{
3. Model of the Prospective Remedy for Patent Infringement
}

Our model has three participants: the Court, the patent holder $P$, and the downstream firm $D$. In the patent infringement case before the Court, the patent holder $P$ is the plaintiff and the downstream firm $D$ is the defendant. We model the situation arising after the Court has ruled that $D$ 's product infringes $P$ 's patent. The question addressed is what prospective remedy the Court will impose. In the game we study, the Court establishes a remedy, based on the evidence presented to the Court, then $D$ and $P$ have the opportunity to negotiate a patent license.

\section{A. Benefits and Costs of Downstream Firm Using Patented Technology}

The state of nature is captured by three non-negative variables, $(\alpha, \beta, \gamma)$.

The variable $\alpha$ represents the loss of profits that $P$ will suffer if $D$ continues to use $P$ 's patented technology rather than design around it. In cases where $P$ and $D$ compete directly, $\alpha$ reflects $P$ 's lost profits because $D$ 's infringing product is better, or lower-cost, than a non-infringing version. The variable $\alpha$ establishes the minimum amount that $P$ would accept from $D$ for a patent license.

evidence that remedies at law are inadequate." However, even when the patent holder and the infringing firm are direct competitors, the Federal Circuit has held that the qualifying irreparable harm must have a "causal nexus" with the patent infringement. See Apple v. Samsung 735 F.3d 1352 at 1360 (2013).

${ }^{21}$ In ActiveVideo v. Verizon 694 F. 3d 1312 at 1337 (2012) the Federal Circuit stated: "In light of the record evidence including ActiveVideo's past licensing of this technology and its pursuit of Verizon as a licensee, no fact finder could reasonably conclude that ActiveVideo would be irreparably harmed by the payment of a royalty (a licensing fee)."

${ }^{22}$ i4i v. Microsoft 598 F. 3d 831 at 863 (2010). It is very difficult to reconcile this statement with Justice Kennedy's concurrence in the eBay case. 
The variable $\omega=\beta+\gamma$ represents the cost that $D$ would have to incur to redesign its product to avoid infringing $P$ 's patent. ${ }^{23}$ Here $\omega$ establishes the maximum amount that $D$ would pay for a patent license from $P$. The redesign cost $\omega=\beta+\gamma$ includes the fixed costs of redesign, any profit margins that $D$ must forego while forced to withdraw its product from the market until the redesigned product is ready for sale, and any decline in profits that $D$ experiences because its non-infringing product is more costly to produce or less attractive to customers.

The redesign $\operatorname{cost} \omega$ is comprised of two components: $\beta$ represents the cost that $D$ would have had to incur to initially design its product to avoid infringing $P$ 's patent. The variable $\beta$ thus establishes the maximum amount that $D$ would have paid for a patent license from $P$ at the time when $D$ initially designed its product. The variable $\gamma$ represents any additional costs that $D$ must bear because the redesign takes place later, after the Court has ruled that $D$ 's product infringes $P$ 's patent. For example, in the case where Toyota was found to infringe Paice's patent on drive trains for electric vehicles, ${ }^{24} \beta$ measures the cost saving to Toyota of using Paice's technology rather than the next-best alternative when Toyota first developed the Prius, and $\gamma$ measures the additional costs that Toyota would incur if later forced to redesign the existing Prius line to avoid infringing. Importantly, these switching costs $\gamma$ can be large even if the ex ante value of the patented technology, $\beta$, is small. See Lemley and Shapiro (2007) and Lee and Melamed (2016).

In state of nature $(\alpha, \beta, \gamma)$, if $D$ redesigns its product to avoid using $P$ 's patented technology, then the payoffs for $[P, D]$ are equal to $[\alpha, 0] .{ }^{25}$ Alternatively, if $D$ uses $P$ 's patented technology and pays royalties $R$ to $P$, then their payoffs are equal to $[R, \beta+\gamma-R]$. Note that $D$ 's use of the patented technology leads to higher joint profits for $P$ and $D$ if and only if $\beta+\gamma>\alpha$.

This way of treating the firms' payoffs is very general. It includes these three fact patterns:

\section{Downstream Firm Serves a New Market}

The downstream firm does not compete against the patent holder or any of its licensees, but instead purely serves a new market. In this case, $\alpha=0$.

\section{Downstream Firm Competes Against the Patent Holder's Licensees}

The downstream firm competes against licensees who pay royalties to the patent holder, and using the patented technology rather than designing around makes $D$ a stronger competitor. In this case, $\alpha$ represents the royalty income lost by $P$ as a result of the downstream firm being a stronger competitor due to its use of the patented technology.

\section{Downstream Firm Competes Against the Patent Holder}

The downstream firm competes against the patent holder, and using the patented technology rather than designing around makes $D$ is a stronger competitor. In this case,

\footnotetext{
${ }^{23} \mathrm{We}$ assume that redesigning is better for $D$ than exit. In some cases, notably those involving standard-essential patents, the downstream might exit rather than redesign, because a non-compliant product may not be commercially viable. In that case, $D$ 's ex post willingness to pay for a patent license is $\beta+\pi$, where $\pi<\gamma$ is the profit $D$ would have earned by initially designing its product to avoid using the patented technology. The analysis below can handle this situation by replacing $\gamma$ with $\pi$.

${ }^{24}$ Paice LLC. V. Toyota Motor Corp., 504 F. 3d 1293 (2007).

${ }^{25}$ We have normalized at zero $D$ 's payoff from redesigning its product to avoid infringing, and $P$ 's payoff if $D$ uses $P$ 's patented technology free of charge.
} 
$\alpha$ represents the patent holder's lost profits that result from the downstream firm being a stronger competitor due to $D$ 's use of the patented technology. ${ }^{26}$

\section{B. Information Available to the Court and Choice of Remedy Regime}

The Court moves first, establishing the prospective remedy regime.

The Court does not observe the state of nature, $(\alpha, \beta, \gamma)$. Evidence has been presented to the Court by $P$ and $D$ regarding $(\alpha, \beta, \gamma)$. Combining that evidence with its prior beliefs, the Court forms a posterior distribution on $(\alpha, \beta, \gamma)$, with density $f(\alpha, \beta, \gamma)$ with bounded support. Whenever we refer to the minimum or maximum of a function of $(\alpha, \beta, \gamma)$, we are mean the minimum or maximum of that function taken over the support of $f(\alpha, \beta, \gamma)$. We denote by $g(\alpha, \beta)$ the density of $(\alpha, \beta)$ after integrating out $\gamma$.

We denote the mean of $f(\alpha, \beta, \gamma)$ by $(a, b, c)$. We refer to $(a, b, c)$ as the Court's best estimate of the relevant costs and benefits associated with $D$ 's use of $P$ 's patented technology. In practice, the courts typically award patent damages (for prior infringement) based on their best estimate of the ex ante benefits and costs associated with $D$ 's use of $P$ 's patented technology, which is $(a, b)$ in our model. One of the key questions we address here is whether the Court's prospective remedy should be based just on the mean $(a, b, c)$ or alternatively should also account for the Court's uncertainty about $(\alpha, \beta, \gamma)$, and if so how.

We study three prospective remedy regimes: (1) Injunction Regime: the Court prohibits $D$ from continuing to use $P$ 's patented technology without a license from $P$; (2) Optimal Royalties Regime: the Court gives $D$ to right to continue to infringe $P$ 's patent if $D$ pays a royalties $r^{*}$, the optimal royalties given the Court's objective of properly compensating the patent holder and given the Court's posterior distribution $f(\alpha, \beta, \gamma)$; and (3) Simple Royalties Regime: the Court gives $D$ to right to continue to infringe $P$ 's patent if $D$ pays the "simple royalties," i.e., the royalties that would maximize the Court's objective of properly compensating the patent holder if the state of nature were known to be $(a, b, c)$.

The Optimal Royalties Regime differs from the Simple Royalties Regime because the optimal royalties $r^{*}$ can be set based on any and all of the evidence presented to the Court, which is encoded in the Court's posterior distribution $f(\alpha, \beta, \gamma)$, while the simples royalties are based only on the Court's best estimate of the relevant costs and benefits, i.e., $(a, b, c)$.

The Injunctions Regime and the Simple Royalties Regime are meant to reflect actual legal practice in the United States. As discussed above, since the eBay case, courts either issue injunctions or establish ongoing royalties. ${ }^{27}$ The Simple Royalties Regime models the court as establishing ongoing royalties based on its best estimate of the relevant benefits and costs of infringement. In cases involving reasonable royalties, the simple royalties are the same as the reasonable royalties that the court has already determined for the purpose of awarding damages for prior infringement. Studying the Optimal Remedies Regime allows us identify the

\footnotetext{
${ }^{26}$ Even if $P$ and $D$ are direct competitors, $\alpha=0$ if the version of $D$ 's product that practices $P$ 's technology provides no stronger competition to $P$ than does the version of $D$ 's product designed to avoid using $P$ 's technology. In terms of patent law, $\alpha=0$ if there is no “casual nexus" between $D$ 's infringement and $P$ 's lost profits.

${ }^{27}$ Courts sometimes use a hybrid regime, under which the infringing firm can continue to sell its infringing product for some period of time, paying royalties established by the court, after which an injunction will apply. This hybrid regime is discussed below in Section 9.
} 
circumstances in which the court can do better by establishing an ongoing royalty rate different from the one the court has used to award patent damages.

By setting the ongoing royalties high enough that the downstream firm will never be willing to pay them, $r>\max [\beta+\gamma]$, the Court can replicate the Injunction Regime. Therefore, the Optimal Royalty Regime subsumes the Injunction Regime as a special case. This implies that the Optimal Royalty Regime must perform at least as well as the Injunction Regime.

Recognizing this fact, our analysis focuses on two related questions. First, we study the ratio of the optimal royalties $r^{*}$ to the simple royalties. This ratio is directly relevant for a court that is setting ongoing royalties. Second, we compare the Injunction Regime with the Simple Royalties Regime. This comparison is directly relevant for a court choosing between issuing an injunction and setting ongoing royalties at the same rate that the court used to award patent damages.

\section{Bargaining Between Patent Holder and Downstream Firm}

After the Court establishes the remedy regime, the patent holder and the downstream firm have the opportunity to bargain over a patent license. We assume that both $P$ and $D$ observe the true state of nature, $(\alpha, \beta, \gamma)$. Whenever the patent holder and the downstream firm bargain and there are positive gains from trade available, we assume they are able to achieve those gains and that the patent holder captures a share $\theta$ of the gains from trade, where $0<\theta<1$.

We make two assumption regarding the bargaining between $P$ and $D$ after the Court has established ongoing royalties. First, we assume that the ongoing royalties serve as an outside option that places an upper bound on what the downstream firm will pay for a patent license, but do not otherwise influence the bargaining outcome. Second, we assume that the patent holder is permitted to pay the downstream firm not to use the patented technology. We discuss both of these assumptions below when we analyze the bargaining stage of the game.

With efficient bargaining between $P$ and $D$ (and no antitrust limits), the remedy regime imposed by the Court has no effect on whether $D$ ends up using the patented technology. Still, by influencing the threat points, the remedy regime does affect how the joint profits are split between $P$ and $D$. The Court cares about this split, because the Court is seeking to fully compensate, but not over-compensate, the patent holder for any ongoing infringement. ${ }^{28}$

\section{The Court's Objective}

The Court's objective is to compensate the patent holder as accurately as possible for any future infringement by $D$. Following patent law, the desired level of compensation is equal to the greater of (a) $P$ 's lost profits, and (b) reasonable royalties. $P$ 's lost profits are equal to $\alpha$. Under patent law, the reasonable royalties are defined to be the royalties to which $P$ and $D$ would have agreed in a hypothetical negotiation taking place prior to $D$ 's infringement. At that time, $D$ would have been willing to pay up to $\beta$ for a license, and $P$ would have been willing to accept as little as $\alpha$. The concept of reasonable royalties only makes sense if there would have been gains from trade at that time, i.e., if $\beta>\alpha$. If $\beta>\alpha$, the hypothetical $e x$ ante negotiation would result

\footnotetext{
${ }^{28}$ Bebchuck (2001) takes a somewhat similar ex ante approach to the choice between property vs. liability rules in the context of controlling externalities.
} 
in the downstream firm paying royalties of $\alpha+\theta(\beta-\alpha)$ to the patent holder. In situations where $\beta>\alpha$, we refer to $\alpha+\theta(\beta-\alpha)$ as the "reasonable royalties."

Putting the two pieces together, in state of nature $(\alpha, \beta, \gamma)$, the greater of lost profits and reasonable royalties is equal to $r(\alpha, \beta) \equiv \max [\alpha, \alpha+\theta(\beta-\alpha)]$. From the Court's perspective, this is the patent holder's desired or benchmark payoff in state of nature $(\alpha, \beta, \gamma){ }^{29}$ The "simple royalties" that define the Simple Royalties Regime are $r(\mathrm{a}, \mathrm{b})=\max [a, a+\theta(b-a)]$. Using the Court's posterior distribution, the patent holder's expected benchmark payoff is given by

$$
\bar{\Pi}=\iint r(\alpha, \beta) g(\alpha, \beta) d \alpha d \beta=a+\theta \iint_{\beta>\alpha}(\beta-\alpha) g(\alpha, \beta) d \alpha d \beta
$$

For convenience, we write this as $\bar{\Pi}=a+\theta * \Delta$, where $\Delta$ also can be expressed as $\Delta=\operatorname{Prob}[\beta>\alpha] * E[\beta-\alpha \mid \beta>\alpha]$.

Suppose that a given remedy regime provides a payoff to the patent holder of $H(\alpha, \beta, \gamma)$ in state of nature $(\alpha, \beta, \gamma)$, with expected payoff $\bar{H}$. The Court's objective is to minimize the absolute value of the difference between the patent holder's expected payoff and the patent holder's expected benchmark payoff, $Z \equiv|\bar{H}-\bar{\Pi}|$. This approach is driven by and firmly rooted in patent law's goal of fully compensating, but not over-compensating, patent holders for any ongoing infringement of their patents.

\section{Negotiations Between the Patent Owner and Downstream Firm}

As usual, we solve the game starting with the final stage. In this Section, we analyze the ex post negotiations between $P$ and $D$ after the Court imposes a remedy. The nature of these negotiations depends upon the ex post state of nature, $(\alpha, \beta, \gamma)$. We divide states of nature $(\alpha, \beta, \gamma)$ into three categories, which are displayed in Figure 1 below:

- Licensing: There were ex ante gains from trade from the downstream firm using the patented technology, so the notion of "reasonable royalties" applies. This happens if $\beta>\alpha$. The ex ante gains from trade are $\beta-\alpha$. In Licensing states of nature, the ex post gains from trade are $\beta+\gamma-\alpha$, which is greater than $\gamma$.

- Lock-In: There are ex post gains from trade, but there were no ex ante gains from trade. This happens if $\beta+\gamma>\alpha>\beta$. In Lock-In states of nature, the ex post gains from trade are $\beta+\gamma-\alpha$, which is positive but less than $\gamma$.

- Redesign: There are no ex post gains from trade, meaning that ex post joint profits are higher if $D$ redesigns its product than if $D$ uses the patented technology. Redesign states of nature occur if $\beta+\gamma<\alpha$.

\footnotetext{
${ }^{29}$ The Court's objective depends on the bargaining parameter $\theta$. This reflects the fact that patent law defines the "reasonable royalties" with reference to a hypothetical negotiation, thereby accepting such market outcomes as the proper or normative reward for patent holders. If a given patent holder has been able to negotiate high royalty rates in licenses with other users of its technology, the courts use those rates as benchmarks for reasonable royalties.
} 


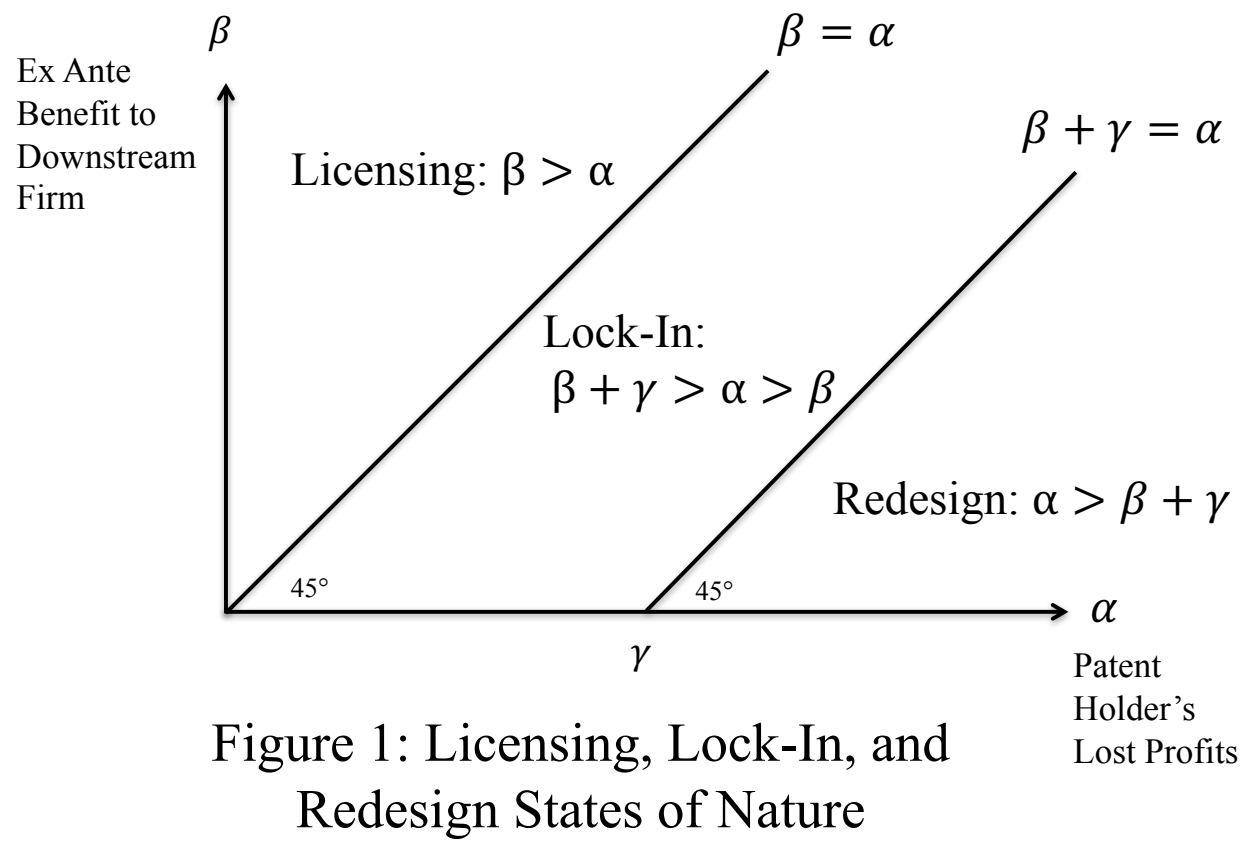

\section{A. Bargaining After an Injunction Has Been Imposed}

If the Court imposes an injunction, and negotiations break down, the downstream firm will redesign its product to avoid infringing. In Redesign states of nature, there are no ex post gains from trade, $D$ redesigns its product, and the firms' payoffs are $[\alpha, 0]$. Note that the patent holder's payoff of $\alpha$ is equal to its benchmark payoff in Redesign states of nature.

In Licensing and Lock-In states of nature, the ex post gains from trade are $\beta+\gamma-\alpha$. Under our assumption of efficient bargaining, the parties sign a license to achieve these gains from trade, with the patent holder capturing a share $\theta$ of the gains from trade. Therefore, $P$ 's payoff in these states of nature is $\alpha+\theta(\beta-\alpha)+\theta \gamma$. The term $\theta \gamma$ reflects $P$ 's ability to opportunistically capture a share of $D$ 's switching costs. In Licensing states of nature, an injunction, by enabling $P$ to engage in patent holdup, over-rewards the patent holder by $\theta \gamma$. In Lock-In states of nature, $P$ 's benchmark payoff is $\alpha$, so an injunction over-rewards the patent holder by $\theta(\beta+\gamma-\alpha)$, which is positive but less than $\theta \gamma .{ }^{30}$

\section{B. Bargaining After Ongoing Royalties Have Been Established}

Suppose that the Court has set the ongoing royalties at $r$. This means that the downstream firm has the unilateral right (option) to continue to sell its infringing product so long as it pays $r$ to the

\footnotetext{
${ }^{30}$ The patent holder captures a share of $D$ 's switching costs, $\theta \gamma>0$, but $P$ also bears a share of the ex ante inefficiency caused by the infringement, $\theta(\beta-\alpha)<0$.
} 
patent holder. Here we take $r$ as given and study the bargaining between $P$ and $D$. Below, in Section 5, we discuss how the Court sets $r$.

\section{Licensing and Lock-In States of Nature}

In Licensing and Lock-In states of nature, ex post joint profits are higher if the downstream firm includes the patented feature in its product, so this will be the negotiated outcome. But the royalty payment from $D$ to $P$ depends on the ongoing royalties $r$ established by the Court.

If $r$ is more than the downstream firm is willing to pay to use the technology, i.e., if $r>\beta+\gamma$, then the option of using the infringing technology and paying $r$ is of no value to $D$. Therefore, ongoing royalties set at $r>\beta+\gamma$ are ex post equivalent to an injunction. So, if $r>\beta+\gamma$, the analysis above tells us that $P$ and $D$ will agree to royalties of $\alpha+\theta(\beta-\alpha)+\theta \gamma$.

If $r$ is less than the royalties that the two parties would negotiate in the face of an injunction, i.e., if $r<\alpha+\theta(\beta-\alpha)+\theta \gamma$, then the downstream firm will simply pay the court-established rate $r$ and continue to sell its infringing product. In this case, by awarding ongoing royalties, the Court crowds out private negotiations.

The remaining possibility is that $r$ is greater than the royalties that the two parties would negotiate in the face of an injunction, but less than the downstream firm's willingness to pay for a license, i.e., $\alpha+\theta(\beta-\alpha)+\theta \gamma<r<\beta+\gamma$. In this situation, we treat $r$ as an outside option that places an upper bound on what $D$ will pay but does not otherwise influence the bargaining outcome. See Binmore, Shaked and Sutton (1989). This implies that $P$ and $D$ will negotiate royalties of $\alpha+\theta(\beta-\alpha)+\theta \gamma$ when $r$ falls in this range. Under this view of bargaining, the downstream firm that has been granted an option to use the patented technology at rate $r$ cannot end up worse off than it would be without that option, i.e., facing an injunction. Our approach is consistent with the observation that patent holders commonly seek injunctions and infringers routinely resist patent holders' requests for injunctions.

Figure 2 shows the patent holder's payoff in Licensing and Lock-In states of nature as a function of the court-awarded royalties $r$. Figure 2 also displays the patent holder's benchmark payoff of $r(\alpha, \beta)$ and the patent holder's payoff under an injunction, $\alpha+\theta(\beta-\alpha)+\theta \gamma$. 


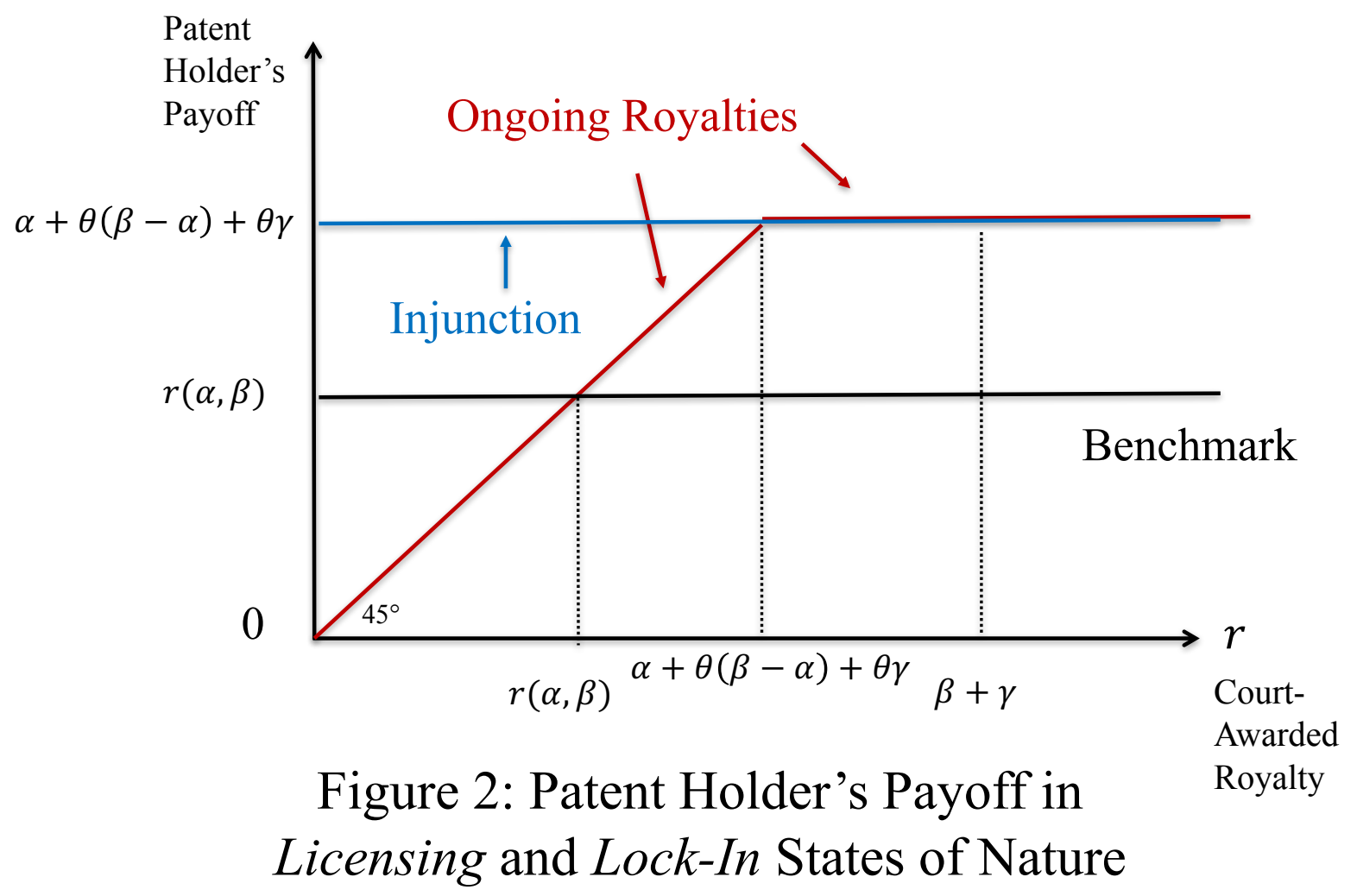

\section{Redesign States of Nature}

In Redesign states of nature, $\alpha>\beta+\gamma$ so the downstream firm's use of the patented technology lowers ex post joint profits. What happens in these states of nature after the Court sets the ongoing royalties at $r$ ? If $r>\beta+\gamma$, so $D$ is unwilling to pay the royalties set by the Court, the ongoing royalty regime is equivalent to an injunction and the outcome is straightforward: $D$ redesigns its product and the patent holder receives its benchmark payoff of $\alpha$.

If $r<\beta+\gamma$, so $D$ is willing to pay the ongoing royalties set by the Court, the situation is a bit trickier. Efficient bargaining in this situation implies that $P$ will pay $D$ to get $D$ to agree not to exercise its option to pay $r$ to use the patented technology.

That type of "reverse payment" from $P$ to $D$ to induce $D$ to be a weaker rival could be seen as an antitrust violation, because this fact pattern bears some resemblance to reverse payments made prior to the determination of patent validity and infringement, which can violate antitrust law. ${ }^{31}$ However, in the current setting the payment from $P$ to $D$ can only serve to correct for the Court's error in under-estimating the harm to the patent holder caused by ongoing infringement, so the analysis is quite distinct and the case for antitrust limits here is far weaker.

\footnotetext{
${ }^{31}$ See Federal Trade Commission v. Actavis, 133 S. Ct. 2223 (2013).
} 
If $r<\beta+\gamma$ and $P$ is permitted to pay $D$ to stop $D$ from using $P$ 's patented technology, then that will be the outcome. The two firms will split the gains from trade, which are $\alpha-(\beta+\gamma)$. P's payoff will then be $r+\theta(\alpha-(\beta+\gamma))$. See Figure 3. ${ }^{32}$ Alternatively, if $r<\beta+\gamma$ and $P$ is prohibited from paying $D$ to stop $D$ from using $P$ 's patented technology, then the downstream firm will use the patented technology and pay $r$ in these states of nature. That outcome gives the patent holder a payoff of $r$. This alternative payoff also is shown in Figure 3.

With or without antitrust limits, if $r<\beta+\gamma<\alpha$, the patent holder is not fully compensated for $D$ 's ongoing infringement. Imposing antitrust limits on reverse payments lowers $P$ 's payoff by $\theta(\alpha-(\beta+\gamma))$ in these states of nature, moving $P$ 's payoff farther away from its benchmark level of $\alpha$. All of the propositions reported below hold whether or not the patent holder is allowed to pay the downstream firm to refrain from using the patented technology. We report simulation results with and without these antitrust limits. When they matter in our simulations, these antitrust limits reduce the performance of the ongoing royalties regime.

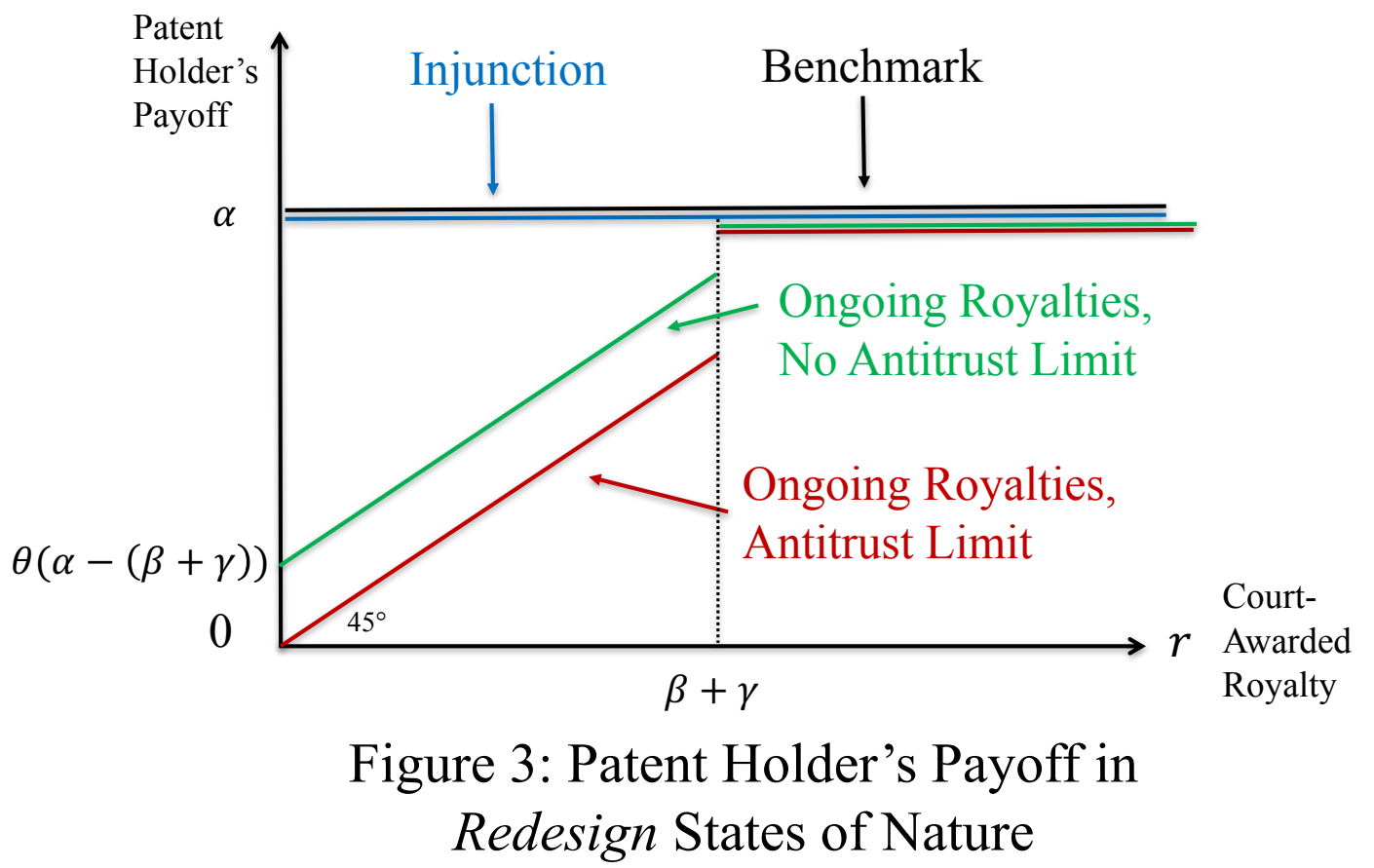

\section{General Results}

In this Section we present our results regarding the three remedy regimes that we are evaluating. All proofs are in the Appendix.

\footnotetext{
${ }^{32}$ The discontinuity in the patent holder's payoff at $r=\beta+\gamma$ results from the fact that $P$ must split the gains from trade with $D$ if $r<\beta+\gamma$, because $D$ will use the patented technology and pay $r<\beta+\gamma$ if bargaining breaks down, but not if $r>\beta+\gamma$, because $D$ will not pay more than $\beta+\gamma$ to use the patented technology.
} 


\section{A. Injunction Regime}

The Injunction Regime has the major advantage of not requiring the court to estimate either the harm to the patent holder that will be caused by ongoing infringement or the benefits of the patented technology to the downstream firm. The Injunction Regime performs perfectly in the absence of patent holdup.

Proposition 1: If the switching costs are known to be zero, then the Injunction Regime perfectly matches the benchmark payoff to the patent holder in each state of nature.

Proposition 1 tells us that the only rationale for using ongoing royalties in our model is to prevent the patent holder from using the bargaining power associated with an injunction to engage in patent holdup, i.e., to extract excessive royalties from the downstream firm based on its switching costs.

Proposition 2 describes the magnitude of patent hold-up in the Injunction Regime in the Licensing, Lock-In, and Redesign states of nature.

Proposition 2: The Injunction Regime: (a) over-rewards the patent holder in Licensing states of nature by $\theta \gamma$; (b) over-rewards the patent holder in Lock-In states of nature by $\theta(\beta+\gamma-\alpha)<\theta \gamma$; and (c) rewards the patent holder at its benchmark level in all Redesign states of nature.

Since the Injunction Regime over-rewards the patent holder in every Licensing and Lock-In state of nature, and properly rewards the patent holder in every Redesign state of nature, the Injunction Regime over-rewards the patent holder in expectation if the Licensing or Lock-In states of nature occur with positive probability.

If the Court is certain that there were ex ante gains from trade, i.e., if $\operatorname{Prob}[\beta \geq \alpha]=1$, then only Licensing states of nature arise, and Proposition 2 tells us that the patent holder's expected reward under the Injunction Regime will exceed the benchmark level by $\theta c$. This expected overreward is unrelated to the magnitudes of $\alpha$ and $\beta$ and can thus be arbitrarily large relative to the patent holder's benchmark reward, $a+\theta(b-a)$.

On the other hand, if the Court is certain that there are no ex post gains from trade between $P$ and $D$, i.e., if $\operatorname{Prob}[\alpha \geq \beta+\gamma]=1$, then only Redesign states of nature arise and the Injunction Regime performs perfectly. This might be the case, for example, if the patent holder would have a monopoly if not for D's infringing product, and if the Court is certain that the duopoly profits plus the downstream firm's switching costs are less than the monopoly profits.

\section{B. Optimal Royalties Regime}

Our next proposition establishes that the Court can provide the patent holder with the benchmark expected payoff $\bar{\Pi}$ using the Optimal Royalties Regime:

Proposition 3: The Optimal Royalties Regime gives the patent holder an expected payoff equal to the benchmark level.

Proposition 4 compares the optimal royalties to those set under the Simple Royalties Regime:

Proposition 4: If the Court is certain there are ex post gains from trade, then the optimal royalties are at least as large as the royalties in the Simple Royalties Regime, $r^{*} \geq \boldsymbol{r}(\boldsymbol{a}, \boldsymbol{b})$. 
To see why the optimal royalties are at least as large as the simple royalties, consider a situation in which the Court is certain there were ex ante gains from trade, so $b>a$. The simple royalties are then given by $r(a, b)=a+\theta(b-a)$. Setting $r=a+\theta(b-a)$ may appear to be the optimal choice for the Court, because the patent holder's benchmark expected return, $\bar{\Pi}$ is equal to $a+\theta(b-a)$. And the patent holder would indeed get exactly this benchmark return if the downstream firm were to pay that the amount set by the Court in every state of nature. However, that need not be the case. When the Court sets the royalties, the Court is giving the downstream firm the option to use the patented technology by paying those royalties, but in some states of nature the downstream firm may be able to negotiate lower royalties. If that happens with positive probability in response to $r=a+\theta(b-a)$, then the Court must elevate the royalties above the level of the simple royalties to give the patent holder is benchmark expected return.

Proposition 5 provides conditions under which no such elevation is necessary, so the optimal royalties are equal to the simple royalties:

\section{Proposition 5: If the Court is certain there were ex ante gains from trade and if} $\min [\alpha+\theta(\beta+\gamma-\alpha)] \geq a+\theta(b-a)$, then the Optimal Royalties Regime coincides with the Simple Royalties Regime, so $r^{*}=a+\theta(b-a)$.

If the inequality in Proposition 5 is satisfied, the Simple Royalties Regime gives the benchmark expected return to the patent holder, even though the Court observes the true state of nature imperfectly. That inequality is satisfied if $\theta * \min [\gamma]>a+\theta(b-a)-\min [\alpha+\theta(\beta-\alpha)]$. Proposition 5 tells us that the Simple Royalties Regime gives the patent holder the benchmark expected payoff if the Court is certain that (a) there were ex ante gains from trade, and (b) the amount the patent holder might extract based on patent holdup if granted an injunction is larger than maximum amount by which the Court may be over-estimating the reasonable royalties.

Proposition 5 gives conditions under which $r^{*} / r(a, b)=1$. In general, the ratio $r^{*} / r(a, b)$ is larger, the greater is the Court's uncertainty about the true state of nature, and the smaller are $D$ 's switching costs. Below, we report results regarding the ratio $r^{*} / r(a, b)$ in certain specific cases.

The Appendix calculates the ratio $r^{*} / r(a, b)$ assuming that $(\alpha, \beta)$ is normally distributed, $\gamma$ is known, and $\theta=0.5 .^{33}$ If $\gamma=\sigma$, the standard deviation with which the Court estimates $\alpha$ and $\beta$, and if $a=b$, meaning that the average harm to the patent holder from infringement equals the average benefit to the downstream firm, then the ratio of the optimal royalty rate to the simple royalty rate $r^{*} / r(a, b)$ is 1.05 . Higher switching costs cause $r^{*} / r(a, b)$ to be slightly lower: if $\gamma=2 \sigma$, then $r^{*} / r(a, b)=1.03$. Likewise, if $\gamma=0.5 \sigma$, then $r^{*} / r(a, b)=1.08$. These results are virtually unchanged as one varies the ratio $a / b$. So, at least for normal distributions, for a wide range of parameters the optimal royalty rate $r^{*}$ is not far above the simple royalty rate $r(a, b)$. The Appendix also reports simulation results using the Pareto Distribution, which has a fatter tail than the normal distribution and thus may better reflect the observed skewness in the

\footnotetext{
${ }^{33}$ All examples and simulations using the normal distribution involve parameters such that the probability of negative values is tiny. One could obtain nearly identical results using truncated normal distributions that exclude negative values and have bounded support.
} 
returns to patents. ${ }^{34}$ If the switching cost is equal to the standard deviation with which the Court estimates $\alpha$ and $\beta$, we get $r^{*} / r(a, b)=1.11$, vs. $r^{*} / r(a, b)=1.05$ with the normal distribution.

\section{Simple Royalties Regime}

The Simple Royalties Regime performs perfectly if the Court observes $(\alpha, \beta)$ without error. The Court simply sets the ongoing royalties at $r(\alpha, \beta)$ in state of nature $(\alpha, \beta)$. More generally, the Simple Royalties Regime performs nearly perfectly if $g(\alpha, \beta)$ is distributed very tightly around its mean $(a, b)$. In that case, the royalties set under the Simple Royalties Regime, $r(a, b)$ will be very close to the optimal royalties in state of nature $(\alpha, \beta, \gamma)$, which are $r(\alpha, \beta)$.

Assuming that the Court's ability to observe $(\alpha, \beta)$ is imperfect, we can identify some general conditions under which the Simple Royalties Regime under-rewards the patent holder:

Proposition 6: If the Court is certain there are ex post gains from trade, but uncertain there were ex ante gains from trade, then the Simple Royalties Regime strictly under-rewards the patent holder.

When the conditions of Proposition 6 are not met, the Simple Royalties Regime can over-reward the patent holder. This can only occur if the Court is uncertain about whether there are ex post gains from trade. The following example shows how this can occur.

Example: Suppose that $\alpha$ takes on two values, $A>0$ with probability $p$, and 0 with probability $1-p$. The expected value of $\alpha$ is thus given by $a=p A$. There is no uncertainty about $\beta$ or $\gamma ; \beta=b$ and $\gamma=c$ for sure. Assume that $p A>b+c$. This implies that $A>b+c$, so the state of nature in which $P$ finds infringement costly is a Redesign state of nature. The benchmark return to the patent holder is $A$ in the state of nature in which $\alpha=A$, and $\theta b$ in the state of nature in which $\alpha=0$. Therefore, the benchmark expected return to the patent holder is $p A+(1-p) \theta b$. Under the Simple Royalties Regime, $r=p A$. Since $p A>b+c, D$ is never willing to pay the courtestablished rate to use $P$ 's patented technology. Therefore, the Simply Royalty Regime is equivalent to the Injunction Regime. In the state of nature in which $\alpha=A$, the patent holder receives its benchmark payoff of $A$. In the state of nature in which $\alpha=0$, the patent holder captures its share of the gains from trade, $b+c$, earning profits equal to $\theta(b+c)$. The expected payoff to the patent holder under the Simply Royalty Regime exceeds the benchmark payoff by $(1-p) \theta c$. In this example, the Simple Royalties Regime, just like the Injunction Regime, over-rewards the patent holder by $\theta c$ in states of nature where $P$ and $D$ have ex post gains from trade.

\section{Comparing the Injunction Regime and the Simple Royalties Regime}

As noted above, the Injunction Regime performs perfectly in the absence of switching costs. This tells us that the Injunction Regime will be superior to the Simple Royalties regime is switching costs are sufficiently small.

\footnotetext{
34 The relevant distribution here is the distribution of errors with which the Court estimates the value of the patented technology to the patent holder and the downstream firm. Skewness in overall value does not necessarily imply skewness in the Court's errors, but it would if the evidence presented to the Court contained little information about the value of the invention in question.
} 
As noted above, the Simple Royalties Regime performs perfectly if the Court observes the state of nature without error. This tells us that the Simple Royalties Regime will be superior to the Injunction Regime if the Court observes the state of nature with sufficient accuracy.

Proposition 7 goes beyond these polar cases by providing conditions under which the Simple Royalties Regime performs better than the Injunction Regime:

Proposition 7: The Simple Royalties Regime performs better than the Injunction Regime if the switching costs are large in the sense that (a) $\operatorname{Prob}[\gamma>|\beta-\alpha|]=1$, and (b) $\theta * \min [\gamma]>\boldsymbol{r}(\boldsymbol{a}, \boldsymbol{b})-\min [\alpha+\theta(\beta-\alpha)]$.

Proposition 7 shows that the Simple Royalties Regime performs better than the Injunction Regime if the switching cost are sufficiently large. The first condition in Proposition 7 requires that the switching costs be larger than the impact that D's use of the patented technology has on the firms' ex ante joint profits. The second condition in Proposition 7 is satisfied if the minimum amount that the patent holder could extract based on patent holdup, if granted an injunction, is larger than amount by which the Court might be over-estimating the payment required to properly compensate the patent holder.

The simulations reported in the Appendix, which assume that $(\alpha, \beta)$ is normally distributed, $\gamma$ is known, and $\theta=0.5$, show that when $a=b$ the Simple Royalties Regime performs better than the Injunction Regime if and only if the switching costs are (roughly) greater than the standard deviation with which the Court estimates $\alpha$ and $\beta$.

\section{Cases Involving Reasonable Royalties and Not Lost Profits}

As reported above, in $61 \%$ of patent infringement cases from 2006 to 2015, the patent damages were based only on reasonable royalties, not on lost profits. In our model, these cases correspond to situations in which the Court knows that there were ex ante gains from trade, i.e., $\beta>\alpha$. We now look at two types of cases in this category.

\section{A. Downstream Firm Serves a New Market}

First, we explore situations in which the downstream firm serves a new market, so it does not compete against the patent or its licensees. In this situation, $\alpha=0 .{ }^{35}$ This implies that the patent holder's benchmark payoff in state of nature $(\beta, \gamma)$ is $\theta \beta$, the expected benchmark payoff is $\theta b$, and the simple royalties are $r=\theta b$. The Injunction Regime over-rewards the patent holder by $\theta \gamma$ in state of nature $(\beta, \gamma)$. The Simple Royalties Regime gives $P$ a payoff of $\min [\theta(\beta+\gamma), \theta b]$ in state of nature $(\beta, \gamma)$. Figure 4 illustrates the patent holder's payoff as a function of $\beta$, for a given $\gamma$, under the Injunction Regime and the Simple Royalties Regime.

\footnotetext{
${ }^{35}$ As noted above, $\alpha=0$ even if the patent holder and the downstream firm are direct competitors, if there is no causal nexus between $D$ 's infringement and any profits lost by $P$.
} 


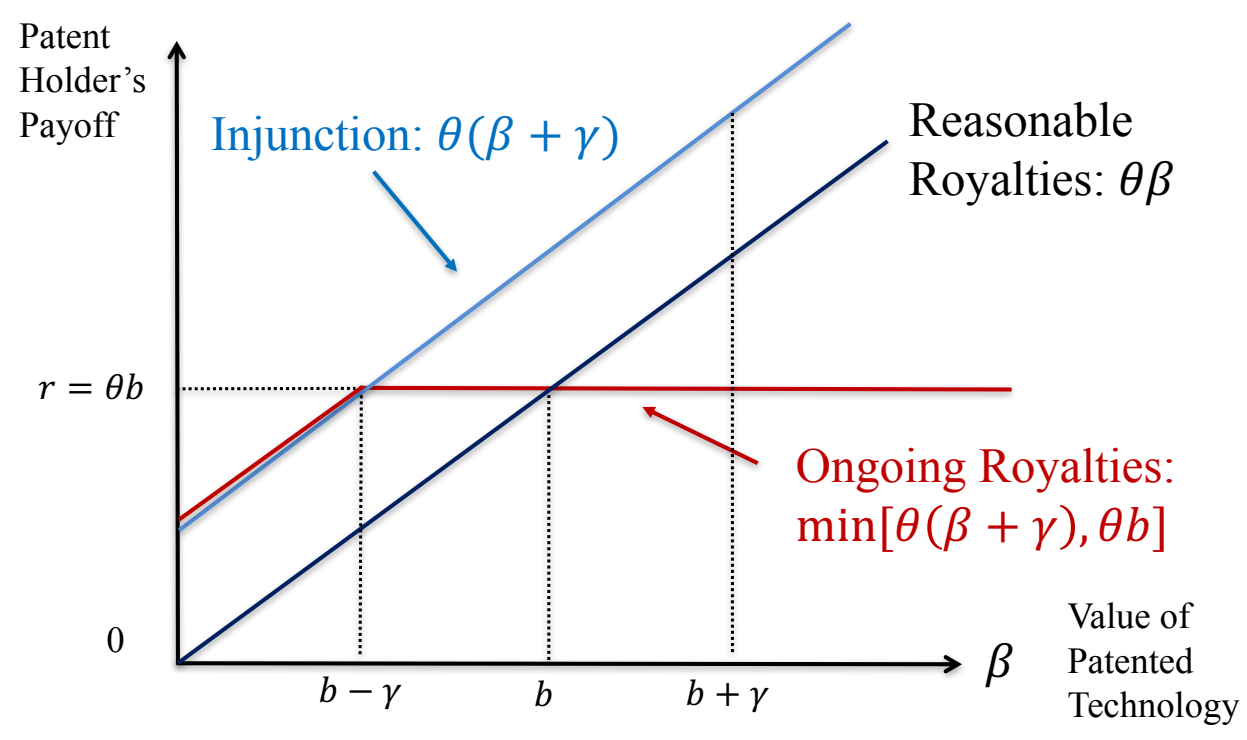

Figure 4: Patent Holder's Payoff $(\alpha=0)$

Based on Figure 4, and applying Proposition 5, we have

Proposition 8: If the downstream firm does not compete against the patent holder or its licensees, then the Simple Royalties Regime, $r=\theta b$, gives the benchmark expected payoff to the patent holder if the Court is certain that $D$ 's ex post willingness to pay for the patented technology exceeds the expected ex ante value of the patented technology, i.e., if $\min [\beta+\gamma]>b$.

Proposition 8 tells us that the Simple Royalties Regime coincides with the Optimal Royalties Regime, i.e., $r^{*}=\theta b$, if $\min [\gamma]>\mathrm{b}-\min [\beta]$. This condition is satisfied if $\min [\gamma]>\mathrm{b}$, i.e., if the Court is certain that the switching cost is larger than the Court's best estimate of the value of the patented technology. This condition will be satisfied in cases where the switching cost is known to be large relative to the value of the patented technology.

If $\min [\gamma]<b-\min [\beta]$, the Simple Royalties Regime under-rewards the patent holder, while the Injunction Regime over-rewards the patent holder. We now explore which regime more closely provides the benchmark expected return to the patent holder. Larger switching costs favor the Simple Royalties Regime, while greater uncertainty about the value of the patented technology favors the Injunction Regime.

The Injunction Regime over-rewards the patent holder by $\theta \gamma$ in state of nature $(\beta, \gamma)$. Therefore, the expected excess return to the patent holder under the injunction regime is $\theta E[\gamma]=\theta c$.

The shortfall in the patent holder's payoff under the Simple Royalties Regime, $r=\theta b$, is

$$
\theta * \operatorname{Prob}[\beta+\gamma<b] * E[b-(\beta+\gamma) \mid \beta+\gamma<b] .
$$


This expression reflects the option value to the downstream firm of negotiating royalties lower than $\theta b$ when $\beta+\gamma<b$. This shortfall will be small if $\operatorname{Prob}[\beta+\gamma<b]$ is small, which will be the case if the switching cost tends to be large relative to the Court's errors in measuring the downstream firm's ex post willingness to pay for the patented technology, $\beta+\gamma$.

\section{Normal Distribution}

If $\beta+\gamma$ follows a normal distribution with mean $b+c$ and standard deviation $\sigma$, the comparison of the two regimes depends only on the ratio $c / \sigma$. The Simple Royalties Regime is superior to the Injunction Regime if and only if $c / \sigma>0.28$. As the switching cost grows relative to the standard deviation of $\beta+\gamma$, the over-reward from the Injunction Regime grows rapidly relative to the under-reward from the Simple Royalties Regime. For example, if $c / \sigma=1$, then the overreward under the Injunction Regime is 12 times as large as the under-reward from the Simple Royalties Regime.

We also can calculate the optimal royalties $r^{*}$ if $\beta+\gamma$ follows a normal distribution. Instead of setting $r=\theta b$, suppose the Court substitutes a higher value $B^{*}$ for $b$, and awards the corresponding ongoing royalty $r^{*}=\theta B^{*}$. We can ask how large $B^{*}$ must be so the patent holder's expected return equals its benchmark level. Let $B^{*}=b+x^{*} \sigma$, so $x^{*}$ measures the gap $B^{*}-b$ in terms of the standard deviation of $\beta+\gamma$. If the switching cost on average is equal to the standard deviation with which the court measures the downstream firm's willingness to pay for the patented technology, $c=\sigma$, then the optimal royalties are 10\% higher than the simple royalties: $x^{*} \approx 0.1$. If $c=2 \sigma$, then $x^{*} \approx 0.01$. Conversely, if $c=\sigma / 2$, then $x^{*} \approx 0.3$. Using the royalties already calculated to award patent damages will work very well unless the Court's best estimate of the switching cost is quite small relative to the Court's uncertainty about how much the downstream firm will pay for the patented technology.

\section{Uniform Distribution}

Now suppose that $\beta+\gamma$ follows a uniform distribution on the interval $[b+c-z, b+c+z]$. Here $z$ reflects the magnitude of the Court's errors in measuring $\beta+\gamma$. Proposition 8 tells us that the Simple Royalties Regime gives $P$ its benchmark expected return if $z \leq c$. For $z>c$, direct calculations show that the comparison of the two regimes depends only on the ratio $k=z / c$. The Simple Royalties Regime scores better than the Injunction Regime if and only if $k<3+4 \sqrt{2} \approx 8.7$. Since we must have $b+c-z \geq 0$ for this example to make sense, $z \leq b+c$, so $k=z / c \leq b / c+1$, and the Simple Royalties Regime must score better if $b / c<7.7$, i.e. if $c>0.13 b$. The Simple Royalties Regime must score better than the Injunction Regime if the Court's best estimate of the switching cost is at least 13\% as large as the Court's best estimate of the value of the patented technology.

When $\beta+\gamma$ follows the uniform distribution, we also can derive an expression for the ratio of the optimal royalties $r^{*}$ to the royalties in the Simple Royalties Regime, which are $\theta b$. We just showed that $r^{*}=\theta b$ if $z \leq c$. If $z>c$, then using $k=z / c$, ratio $r^{*} / \theta b$ is given by

$$
\frac{r^{*}}{\theta b}=1+\frac{c}{b}(1+k-2 \sqrt{k})
$$

To illustrate, suppose that the Court's best estimate of the switching cost is equal to the Court's best estimate of the value of the patented technology, so $b=c$. If the expected switching cost is equal to $50 \%$ of the difference between the Court's best estimate of $\beta+\gamma$, which is $b+c$, and 
its minimum value, then $k=2$ and the optimal royalties are $17 \%$ larger than the Court's best point estimate of royalties. If the expected switching costs are $80 \%$ of the difference between $b+c$ and the minimum value of $\beta+\gamma$, then $k=1.25$ and the optimal royalties are only $1.4 \%$ larger than the Court's best estimate of royalties.

\section{B. Downstream Firm Competes Against the Patent Holder's Licensees}

Next, we consider cases in which the downstream firm competes against the patent holder's licensees. In these cases, the harm to the patent holder caused by $D$ 's infringement results from the royalty income that $P$ loses from its other licensees as a result of $D$ using the patented technology. Suppose that a share $\delta<1$ of the benefits that $D$ obtains from using the patented technology come from displacing royalties that $P$ would otherwise receive from its licensees. This implies that $\alpha=\delta \beta$. This could occur, for example, if $D$ 's margin is equal to the cost advantage that $D$ has over $P$ 's other licensees as a result of $D$ not paying royalties to $P$, and if $\delta$ is the share of $D$ 's sales that are diverted from $P$ 's other licensees.

With $\alpha=\delta \beta$, there are always ex ante gains from trade, so the patent holder's benchmark payoff in state of nature $(\alpha, \beta, \gamma)$ is given by $\alpha+\theta(\beta-\alpha)$ which is equal to $(\theta+\delta(1-\theta)) \beta$. If $\delta=0$, the downstream firm serves a new market and $P$ 's benchmark payoff is $\theta \beta$. That corresponds to the case studied just above. At the other extreme, $\delta=1, D$ entirely displaces sales from $P$ 's other licensees. In that case, $\alpha=\beta$ and $P$ 's benchmark payoff is $\beta$, the full value of $D$ 's ex ante willingness to pay for a license. Again applying Proposition 5, we have

Proposition 9: If the downstream firm competes against the patent holder's licensees and $\alpha=\delta \beta$, then the Simple Royalties Regime gives the benchmark expected payoff to the patent holder if $\theta * \min [\gamma]>(\theta+\delta(1-\theta))(b-\min [\beta])$.

Since $\delta \leq 1$, Proposition 9 tells us that a sufficient condition for the Simple Royalties Regime to give the benchmark expected return to the patent holder is that $\theta * \min [\gamma]>b-\min [\beta]$. If $P$ and $D$ split the gains from trade, so $\theta=1 / 2$, this condition becomes $\min [\gamma]>2(b-\min [\beta])$. Again we see that the Simple Royalties Regime performs very well if the switching costs are large relative to the Court's uncertainty about the value of the patented technology.

\section{Impact of Remedy Regime on Innovation and Ex Ante Licensing}

The analysis just presented takes as given that the Court's objective is to compensate the patent holder as accurately as possible for any future infringement by the downstream firm. This is the stated goal of patent remedies law (apart from enhanced damages for willful infringement). In this section, we discuss how the prospective remedies regimes studied here compare in providing incentives for firms to innovate and to engage in ex ante licensing.

\section{A. Incentives to Innovate}

The patent system encompasses many instruments that affect the value of obtaining a patent and thereby influence innovation incentives, including: patent length, the procedures by which the U.S. Patent and Trademark Office handles patent applications and approves claims in those applications, the presumption of validity afforded to a patent holder when it asserts its patent in court, the ease with which a patent holder can obtain a preliminary injunction to stop alleged infringement while the court assesses the patent's validity and the patent holder's claim of 
infringement, and the remedies available to a patent holder when the court finds that its patent has been infringed.

This paper takes the view that the patent system as a whole has been set up by Congress to efficiently serve its constitutional function of promoting innovation. Patent remedies, including the prospective patent remedies studied here, are just one part of that overall patent system. As explained in Section 2, patent law seeks to compensate the patent holder for any infringement, no more and no less. ${ }^{36}$ Taking this view, over-rewarding or under-rewarding patent holders for infringement would disrupt the balance of the patent system as a whole and thus be less effective at providing innovation incentives. As usual, it is important to bear in mind that a great deal of innovation occurs by firms that are the targets of patent assertions, as well as by patentees. ${ }^{37}$

As emphasized by Lee and Melamed (2016), some "innocent" infringement is inevitable, due to the large number of patents, their probabilistic nature, and their vague boundaries. Feldman and Lemley (2015) present evidence that patent licensing demands rarely lead to technology transfer. Since the patent system lacks an independent invention defense, investments by firms to develop new products are discouraged to the extent that those firms may end up being "innocent" infringers who will later be required to compensate some patent owner for the harm caused by their infringement. Arguably, in a more balanced system such an independent inventor would face less liability for patent infringement. Indeed, with a robust independent invention defense, or broader prior user rights, the downstream firm would not be liable at all for patent infringement if it developed its product on its own. ${ }^{38}$ One way to place greater weight on the incentives of downstream firms to develop new products would be to reduce the awards given by the courts to patent holders whose patents have been infringed based on products developed independently. In the model studied here, where the Injunction Regime tends to over-reward patent holders and the Simple Royalties Regime tends to under-reward patent holders, moving in that direction would suggest a shift away from the use of injunctions.

\section{B. Incentives to Engage in Ex Ante Licensing}

We now ask how the use of injunctions vs. ongoing royalties affects the incentives of patent holders and downstream firms to engage in ex ante licensing. In situations where ex ante licensing is practical, and there are gains from trade, that outcome seems far preferable to the sequence of events that we have assumed so far: (1) the introduction by $D$ of an infringing product, causing (2) $P$ to sue $D$ for patent infringement, followed by (3) the award by the court of damages for past infringement together with a prospective remedy.

As stressed above, in many cases, especially in the high-tech sector, ex ante licensing is not practical due to the large number of patents that can read on a single product, the probabilistic nature of those patents, and the imprecision of the patent claims. Nonetheless, there are no doubt actions that both patent holders and downstream firms can take to facilitate more ex ante

\footnotetext{
${ }^{36}$ Enhanced damages to deter willful infringement, not studied here, are the exception.

${ }^{37}$ Recognizing that the "downstream firm" is often an innovator in its own right, one can interpret the analysis here as relating to how the total rewards are split between an initial innovator and a follow-on innovator, in the tradition of Green and Scotchmer (1995). See also Bessen and Maskin (2009).

${ }^{38}$ Shapiro (2006) studies the impact of the independent invention defense on innovation incentives. Vermont (2006) argues in favor of an independent defense.
} 
licensing. Patent holders can make their patent claims more precise, and downstream firms can search more diligently to identify patents they might be infringing so they can initiate licensing discussions. Patent holders and downstream firms certainly have some incentive to engage in $e x$ ante licensing, to avoid litigation costs if nothing else. Beyond that, how do injunctions compare with ongoing royalties in providing incentives to sign licenses ex ante at reasonable royalty rates, in situations where there are ex ante gains from trade?

Begin with the patent holder. Under an injunction regime, the patent holder can have a strategic incentive to remain in the background and assert its patent later, after a target firm has made investments that are specific to the patented technology. Before U.S. patent law was changed so that most patent applications are published after 18 months, some patent applicants delayed the prosecution of their patents for years so they could later assert "submarine patents" against firms with high switching costs. Even now, many patent applicants prefer to delay the prosecution of their patents. ${ }^{39}$ Furthermore, for probabilistic patents, if the patent holder and the downstream firm anticipate that the ex post remedy will be an injunction, their ex ante negotiations will tend to result in royalties in excess of the level of reasonable royalties. ${ }^{40}$

What about the incentives of downstream firms who are developing new products to clear those products in advance by signing ex ante patent licenses? In some cases, downstream firms may figure that the patent owner will not sue them because their infringement will not be detected or because the expected award will not be insufficient to cover litigation costs. Those cases may well constitute "willful infringement" and thus qualify for enhanced damages, which are beyond the scope of this article. One advantage of courts using ongoing royalties is that they give the downstream firm an incentive to sign an ex ante license, so long as the ex ante royalties are equal to the court's ongoing royalties multiplied by the patent strength, i.e., the probability that the patent holder will prevail in litigation. Critically, the court's ongoing royalties must truly reflect the assumption that the patent is valid and infringed. In any event, under current patent law, a downstream firm arguably has a strong incentive to identify and license patents in advance, since it will be required to fully compensate the patent holder if its product is later found to be infringing. ${ }^{41}$ The benchmark used in the analysis above reflects that strong incentive.

\section{Practical Implications for Prospective Patent Remedies}

We now translate the findings from our analysis into practical recommendations for courts. ${ }^{42}$ These recommendation are directed to cases in which a finding of infringement has been made and in which the patent holder is seeking a permanent injunction. The discussion immediately below assumes that the court must then decide, following the four-factor test from eBay, whether

\footnotetext{
${ }^{39}$ See, for example, Harhoff (2016) and the papers cited therein.

${ }^{40}$ See Lemley and Shapiro (2007), Shapiro (2010) and Shapiro (2016).

${ }^{41}$ Enhanced damages for willful infringement boost these incentives and thus serve to deter "guilty" infringement. Lee and Melamed (2016, p. 46) state "we call an infringer 'guilty' if it could cost-effectively have avoided infringement by negotiating a license ex ante, but chose instead to infringe."

${ }^{42}$ When applying the results from our model to various settings, all variables represent the present discounted value of the corresponding variable over the remaining lifetime of the patent.
} 
to issue a permanent injunction or establish ongoing royalties. ${ }^{43}$ Following this discussion, we consider two more creative remedy regimes that may well be superior to either of these regimes.

Our analysis indicates that the court should carefully assess the switching costs that the infringing party would incur if forced to stop selling infringing products. These switching costs include the out-of-pocket costs of redesigning the product plus any disruption costs that the downstream firm would bear during the redesign stage. If these switching costs are small relative to the value of the patented technology, an injunction is likely to be the better remedy. In terms of the eBay four factors, if the downstream firm's switching costs are small, the balancing of harms favors the patent holder.

Conversely, if the court believes it can measure the harm to the patent holder caused by infringement and the benefits to the downstream firm from infringement with a high degree of accuracy, then ongoing royalties are likely to be the better remedy. In terms of the eBay four factors, this is the situation in which there is no irreparable harm and monetary damages are adequate to compensate the patent holder.

To go beyond these rules of thumb, it is helpful to distinguish between cases in which the patent owner has been awarded damages based on reasonable royalties and those in which the patent holder has been awarded damages based on lost profits.

\section{A. Reasonable Royalties}

Since the $e$ Bay decision, the lower courts have granted $21 \%$ of the requests for permanent injunctions when the patent holder and the infringing firm are not competitors, and only $16 \%$ of the permanent injunctions requested by Patent Assertion Entities. ${ }^{44}$ Typically, PAEs do not meet the irreparable harm prong of the four-factor test, since they are only seeking monetary damages. However, in a handful of cases the courts have found that PAEs would suffer irreparable harm from ongoing infringement.

In cases where patent damages have been awarded based on reasonable royalties, the royalty rate used to compute those damages is the court's best estimate of the royalty rate that would have been negotiated ex ante assuming the patent is valid and infringed. In terms of our model, these are the ongoing royalties that the court would set under the Simple Royalties Regime. Lemley (2011) and Cotter (2013) argue for setting the ongoing royalty rate using this simple rule. ${ }^{45}$ However, the Federal Circuit has endorsed the awarding of ongoing royalties that differ from the reasonable royalties used for damages based on "changed circumstances." Table 5) reports that the median ongoing royalty rate set by the courts was $34 \%$ higher than the reasonable royalty rate used for retrospective damages.

Our analysis is directly relevant to this debate. This debate is exactly the comparison between the Simple Royalties Regime and the Optimal Royalties Regime, in cases where the court is

\footnotetext{
${ }^{43}$ We do not address the form taken by the ongoing royalties. Lemley (2011) addresses that issue.

${ }^{44}$ Seaman (2016), Figures 3 and 4.

45 "Thus, the answer to how to set the ongoing royalty seems straightforward: it is the royalty the jury set for past damages assuming validity and infringement." Lemley $(2011$, p. 702). The courts "should use the same ex ante license terms [for ongoing royalties] used in setting retrospective royalties." Cotter (2013, p. 127).

${ }^{46}$ See Amado v. Microsoft 517 F. 3d 1293 (2007) and ActiveVideo vs. Verizon 694 F. 3d 1312 (2012).
} 
confident that there were ex ante gains from trade. According to Proposition 4, the royalty rate that properly compensates the patent holder is at least as large as the royalty rate used to determine patent damages. Proposition 5 provides a condition under which setting ongoing royalties at the same rate used for patent damages is optimal, i.e., will properly compensate the patent holder for ongoing infringement by the defendant. This condition is satisfied if the amount the patent holder could extract from the downstream firm based on that firm's switching costs is at least as large as the amount by which the court may be over-estimating the reasonable royalties. In situations where the downstream firm is serving a new market, this condition is satisfied if the court is confident that the downstream firm's switching costs exceed its estimate of the value of the patented technology to the downstream firm (see Proposition 8). When these conditions are not satisfied, our analysis provides guidance on the ratio between the ongoing royalty rate and the rate used to calculate damages (the ratio $r^{*} / r(a, b)$ in our model). Higher switching costs, and greater precision in the court's ability to measure the reasonable royalties, both imply that this ratio should be closer to unity.

Our analysis also is directly relevant for a court choosing between issuing an injunction and setting the ongoing royalty rate at the level used to award damages. This is exactly the comparison between the Injunction Regime and the Simple Royalties Regime in our model. When the condition in Proposition 5 is met, the Simple Royalties Regime performs better than the Injunction Regime. However, the Injunction Regime performs better if the downstream firm's switching costs are small relative to the accuracy with which the court assesses reasonably royalties. In our example with a normal distribution, this happens if the switching costs are less than about $25 \%$ of the standard deviation by which the court estimates the reasonable royalties. In contrast, if the switching costs are large relative to plausible values of the reasonable royalties, the Simple Royalties Regime is markedly superior to the Injunction Regime. ${ }^{47}$

\section{B. Lost Profits}

Since the $e B a y$ decision, the lower courts have typically - but not always - found irreparable harm when the infringing firm competes against the patent holder. Requests for permanent injunctions in such cases have been granted $84 \%$ of the time. ${ }^{48}$ The courts recognize that measuring the impact of ongoing infringement on the patent holder's profits can be very difficult in such cases. This is especially true in markets where competitive conditions are dynamic.

In lost-profits cases, our model suggests that the court first ask whether the harm to the patent holder from ongoing infringement exceeds the value to the downstream firm of continuing to use the patented technology, which includes the avoidance of the switching costs. If the court is confident that the harm to the patent holder exceeds the benefit to the downstream firm, including that firm's switching costs, an injunction is likely to be the better remedy. This happens if the reduction in joint profits caused by competition between the two firms $(\alpha-\beta$ in

\footnotetext{
47 The ongoing royalties regime offers a further distinct advantage in situations where there are ex post gains to trade from licensing but the parties may fail to achieve these gains from trade due to bargaining inefficiency. Both firms may be better off if the downstream firm pays the court-awarded royalty rate and uses the patented technology than if the downstream firm refrains from using the patented technology as a result of a bargaining impasse. For a recent discussion of property rights and bargaining efficiency, see Segal and Whinston (2014).

${ }^{48}$ Seaman (2016), Figure 4.
} 
our model) reduces the two firms' joint profits by more than the redesign costs ( $\gamma$ in our model). In our model, this correspond to situations in which Prob[Redesign] is close to unity.

If the court believes there were no ex ante gains from trade, but there are ex post gains from trade due to significant switching costs, then court should compare the magnitude of those switching costs to the accuracy with which the court believes it can assess the patent holder's lost profits. If the switching costs are smaller than the standard deviation of the court's estimate of lost profits, then injunctions are likely to perform better in compensating the patent holder for the infringement. In cases where the infringing firm is an important rival to the patent holder and there is a causal nexus between the downstream firm's infringement and the patent holder's lost profits, the court may find it very difficult to assess the patent holder's future lost profits with confidence, especially if the remaining lifetime of the patent is long. The hardest cases will be those in which (a) the patent holder's prospective lost profits are very difficult to assess and (b) the downstream firm's switching costs are large.

If the court does award ongoing royalties, but the patent holder then offers to pay the downstream firm to refrain from using the patented technology, that is a signal that the court has set the ongoing royalties at a level that does not properly compensate the patent holder for ongoing infringement. If permitted under the antitrust laws, allowing the patent holder to pay the downstream firm not to use the patented technology would reduce the amount by which the patent holder is under-rewarded for the ongoing infringement.

Our analysis has assumed that the court's estimate of lost profits is unbiased and unpredictable. If there are significant components of lost profits that are very difficult to measure and thus are simply not counted by the court, despite the best efforts of the patent holder, then these assumptions will not be met. If the courts systematically under-estimate patent holders' lost profits, awarding ongoing royalties will perform less well than our analysis indicates, tipping the balance in the direction of using injunctions instead. Plus, if the court's estimate of the patent holder's lost profits is not only biased downward but predictable for certain types of patents, then innovation could well be discouraged in technology areas where the courts predictably under-reward patent holders. Further work is needed to identify areas where the courts are likely to systematically under-estimate lost profits caused by ongoing infringement.

\section{Summary}

In summary, while the lower courts have been faithful to the Supreme Court's eBay decision by avoiding categorical rules, a general pattern has developed in which competitors typically obtain injunctions and non-practicing entities typically do not. The model developed in this article shows how this pattern can emerge as the optimal approach to remedies when courts have imperfect information and find it more difficult to measure lost profits than reasonable royalties.

Our model also provides guidance to the courts regarding the circumstances in which departures should be made from the rule of thumb of granting injunctions if but only if the infringing firm is an important competitor to the patent holder. The model indicates that the courts should give considerable weight to the switching costs, including disruption costs, that the infringing party would incur if forced to redesign its product to avoid infringement. Ongoing royalties can be superior in lost-profits cases if the switching costs are large relative to the accuracy with which lost profits are measured. Conversely, injunctions can be superior in reasonable-royalty cases if 
the downstream firm's switching costs are small relative to the accuracy with which reasonable royalties are measured.

\section{Two Creative - and Very Possibly Superior - Remedy Regimes}

We close by suggesting two hybrid remedy regimes that appear to be feasible and may be superior to the more basic remedy regimes studied above. We leave for future work the more general question how to use the methods of mechanism design to create prospective remedy regimes for patent infringement cases that are workable in practice and perform even better. ${ }^{49}$

\section{A. Ongoing Royalties Followed by an Injunction}

The court can allow the downstream firm to continue to infringe and pay ongoing royalties for a limited period of time, after which an injunction will go into effect. Equivalently, the court can stay its permanent injunction and require the downstream firm to pay ongoing royalties until that injunction goes into force. For example, the court may allow the downstream firm to continue to sell its existing product, paying ongoing royalties, but require the downstream firm to design its next model to avoid infringing the patent.

Lemley and Shapiro (2007) suggest that courts stay injunctions to allow the downstream firm time to redesign its product. Stays on permanent injunctions can be characterized as a hybrid remedy: ongoing royalties for some period of time followed by a permanent injunction. Courts frequently issue stays on permanent injunctions, e.g., in the form of "sunset" provisions on royalties that must be paid until the injunction goes into force. ${ }^{50}$

Awarding ongoing royalties followed by an injunction has the advantage of limiting patent holdup, yet also limiting court errors in cases where the court underestimates the harm to the patent holder caused by ongoing infringement. This hybrid remedy regime is most promising when the out-of-pocket redesign costs are relatively small, yet the overall switching costs are large due to the opportunity cost of sales the downstream firm would lose if forced to withdraw its product while it completes the redesign process. ${ }^{51}$ When these opportunity costs are large, and when the court's estimate of the royalties necessary to compensate the patent holder for infringement is inaccurate, this regime can be markedly superior to either of the pure remedy regimes, ongoing royalties and injunctions.

\section{B. Injunction With a Ban on Licensing}

The court could offer the patent holder a choice between two remedies: (a) ongoing royalties at some specified level, or (b) an injunction together with a court order prohibiting the patent holder

\footnotetext{
${ }^{49}$ Maskin (1999) shows that a very broad range of social choice rules can be implemented as Nash Equilibria using a suitable mechanism if there are three or more individuals. In the context of prospective patent remedies, which mechanisms are workable in practice, and how well they perform, remain open questions.

${ }^{50}$ See, for example, ActiveVideo v. Verizon 694 F. 3d 1312 at 1342.

${ }^{51}$ If the out-of-pocket redesign costs are small, it may be efficient for the infringing party to undertake the redesign effort prior to the conclusion of the patent infringement case, in which case the permanent injunction need only be stayed for a relatively short period of time, if at all.
} 
from licensing its patent to the downstream firm. ${ }^{52}$ This clever remedy works its magic by having patent holders self-select by choosing between the two remedies.

In our model, in Redesign states of nature, where joint profits are higher if the downstream firm redesigns its product, the patent owner will seek and obtain an injunction under this hybrid remedy regime. In Licensing and Lock-In states of nature, where ex post licensing is efficient, the patent holder may opt for ongoing royalties, which tend to perform well in these regions. However, this approach, while very clever, is not perfect. Depending on the state of nature, the bargaining parameter, and the level at which the court sets the ongoing royalties, the patent holder may inefficiently select an injunction in some Licensing and Lock-In states of nature.

In cases where the court knows that the patent holder will not be harmed by the infringement and is simply seeking to maximize its royalties, the court knows that the patent holder will opt for ongoing royalties, so this hybrid regime will coincide with the ongoing royalties regime. However, in cases where the court is uncertain whether ongoing infringement raises or lowers joint profits, this hybrid regime can perform significantly better than either of the two pure remedy regimes, ongoing royalties and injunctions, without imposing any additional informational requirements on the court.

\footnotetext{
${ }^{52}$ Lee and Melamed (2016, p. 62) state: "Precluding bargaining chip injunctions ensures that the patent holder will seek an injunction only if excluding the infringer is efficient." The court could enforce the prohibition on licensing after an injunction is awarded in a number of ways. For example, the injunction could state that the defendant is prohibited from using the patented technology until the earlier of (i) the expiration of the patent or (ii) the first date on which the patent holder accepts consideration from the defendant in exchange for the right to use the technology.
} 


\section{References}

Anton, James and Dennis Yao (2007), "Finding 'Lost' Profits: An Equilibrium Analysis of Patent Infringement Damages,” 23 Journal of Law, Economics \& Organizations 186-207.

Bebchuck, Lucian (2001), "Property Rules vs. Liability Rules: The Ex Ante View of the Cathedral," 100 Michigan Law Review 601.

Bessen, James and Eric Maskin (2009), "Sequential Innovation, Patents, and Imitation," 40 Rand Journal of Economics 611-635.

Binmore, Ken, Avner Shaked and John Sutton (1989), “An Outside Option Experiment,” 104 Quarterly Journal of Economics 753-770.

Calabresi, Guido and A. Douglas Melamed (1972), "Property Rules, Liability Rules, and Inalienability: One View of the Cathedral," 85 Harvard Law Review 1089-1128.

Coase, Ronald (1960), “The Problem of Social Cost," 3 Journal of Law and Economics 1-44.

Contreras, Jorge and Richard Gilbert (2015), “A Unified Framework for RAND and Other Reasonable Royalties,” 30 Berkeley Technology Law Journal 1451-1504.

Cotropia, Christopher and Mark Lemley (2009), "Copying in Patent Law," 87 North Carolina Law Review 1421-1466.

Cotter, Thomas (2013), Comparative Patent Remedies, Oxford University Press.

Cotter, Thomas and John Golden (2015), "Empirical Studies Relating to Patents: Remedies," in Research Handbook on the Economics of Intellectual Property Law, Peter Menell, David Schwartz and Ben Depoorter, eds. Edward Elgar, forthcoming.

Federal Trade Commission, (2011), "The Evolving IP Marketplace: Aligning Patent Notice with Remedies and Competition."

Feldman, Robin and Mark Lemley (2015), “Do Patent Licensing Demands Mean Innovation?” 101 Iowa Law Review 137-189.

Gergen, Mark, John Golden, and Henry Smith (2012), “The Supreme Court's Accidental Revolution? The Test for Permanent Injunctions," 112 Columbia Law Review 203-249.

Green, Jerry and Suzanne Scotchmer (1995), "On the Division of Profits in Sequential Innovation," 26 Rand Journal of Economics 20-33.

Harhoff, Dietmar (2016), "Patent Quality and Examination in Europe," 106 American Economic Review Papers and Proceedings 193-197.

Kaplow, Louis and Steven Shavell (1996a), "Property Rules Versus Liability Rules: An Economic Analysis," 109 Harvard Law Review 713-790.

Kaplow, Louis and Steven Shavell (1996b), "Accuracy in the Assessment of Damages," Journal of Law and Economics, 39:191-210.

Lee, William and A. Douglas Melamed (2016), "Breaking the Vicious Cycle of Patent Damages," 101 Cornell Law Review 385-466, at http://papers.ssrn.com/sol3/papers.cfm?abstract $\mathrm{id}=2577462$. 
Lemley, Mark (2011), “The Ongoing Confusion Over Ongoing Royalties," 76 Missouri Law Review 695-707.

Lemley, Mark and Carl Shapiro (2007), "Patent Holdup and Royalty Stacking," 85 Texas Law Review 1991-2049, at http://faculty.haas.berkeley.edu/shapiro/stacking.pdf.

Maskin, Eric (1999), "Nash Equilibrium and Welfare Optimality," 66 Review of Economic Studies 23-38.

Menell, Peter and Michael Meurer (2013), "Notice Failure and Notice Externalities," 5 Journal of Legal Analysis 1-59, at http://jla.oxfordjournals.org/content/5/1/1.full.pdf $+\mathrm{html}$.

Polinsky, A. Mitchell and Steven Shavell (2014), "Costly Litigation and Optimal Damages," 37 International Review of Law and Economics, 86-89.

PWC (2016), “2016 Patent Litigation Study: Are We at an Inflection Point?” at https://www.pwc.com/us/en/forensic-services/publications/assets/2016-pwc-patentlitigation-study.pdf.

Schankerman, Mark and Suzanne Scotchmer (2001), "Damages and Injunctions in Protecting Intellectual Property," 32 Rand Journal of Economics 199-220.

Seaman, Christopher (2015), “Ongoing Royalties in Patent Cases After eBay: An Empirical Analysis and Proposed Framework," 23 Texas Intellectual Property Law Journal 203249, at http://papers.ssrn.com/sol3/papers.cfm?abstract $\mathrm{id}=2617789$.

Seaman, Christopher (2016), "Permanent Injunctions in Patent Litigation After eBay: An Empirical Study," 101 Iowa Law Review 1949-2018, at https://works.bepress.com/christopher seaman/.

Segal, Ilya and Michael Whinston (2014), "The Efficiency of Bargaining Under Divided Entitlements," 81 University of Chicago Law Review 273-289.

Shapiro, Carl (2000), "Navigating the Patent Thicket: Cross-Licenses, Patent Pools, and Standard Setting," Innovation Policy and the Economy, at http://faculty.haas.berkeley.edu/shapiro/thicket.pdf.

Shapiro, Carl (2006), "Prior User Rights," 96 American Economic Review Papers \& Proceedings 92-96, at http://faculty.haas.berkeley.edu/shapiro/prior.pdf.

Shapiro, Carl (2010), "Injunctions, Hold-Up, and Patent Royalties," 12 American Law and Economic Review 280-318, at http://faculty.haas.berkeley.edu/shapiro/royalties.pdf.

Shapiro, Carl (2016), "Patent Remedies," 106 American Economic Review Papers \& Proceedings 198-202, at http://faculty.haas.berkeley.edu/shapiro/patentremedies.pdf

Vermont, Samuel (2006), "Independent Invention as a Defense to Patent Infringement," 105 Michigan Law Review 475-504. 


\section{Appendix}

Proposition 1: If the switching costs are known to be zero, then the Injunction Regime perfectly matches the benchmark payoff to the patent holder in each state of nature.

\section{Proof of Proposition 1}

In Redesign states of nature, the Injunction Regime gives the patent holder its benchmark payoff of $\alpha$. There are no Lock-In states of nature when $\gamma=0$. In Licensing states of nature, the injunction regime gives the patent holder a payoff of $(1-\theta) \alpha+\theta \beta+\theta \gamma$. For $\gamma=0$ this is equal to the patent holder's benchmark payoff in these states of nature, $(1-\theta) \alpha+\theta \beta$.

Proposition 2: The Injunction Regime: (a) over-rewards the patent holder in Licensing states of nature by $\theta \gamma$; (b) over-rewards the patent holder in Lock-In states of nature by $\theta(\beta+\gamma-\alpha)<\theta \gamma$; and (c) rewards the patent holder at its benchmark level in all Redesign states of nature.

\section{Proof of Proposition 2}

In Redesign states of nature, the Injunction Regime gives the patent holder its benchmark payoff of $\alpha$. In Lock-In states of nature, the payoff to the patent holder under the Injunction Regime is $(1-\theta) \alpha+\theta \beta+\theta \gamma$. Since $\beta+\gamma>\alpha$ in these states of nature, this exceeds the benchmark level of $\alpha$. In Licensing states of nature, the payoff to the patent holder under the Injunction Regime is $(1-\theta) \alpha+\theta \beta+\theta \gamma$, which exceeds the benchmark level by $\theta \gamma$.

Proposition 3: The Optimal Royalties Regime gives the patent holder an expected payoff equal to the benchmark level.

\section{Proof of Proposition 3}

If the royalties are set at $r=0$, the downstream firm will surely use the patented feature, and the patent holder will receive no royalty payment, so the patent holder's payoff is always zero. This under-rewards the patent holder in expectation, compared with its benchmark expected payoff of $\bar{\Pi}$. If the royalties are set at $r=\max [\beta+\gamma]$, the royalties regime is equivalent to the Injunction Regime, under which the patent holder's expected reward is at least $\bar{\Pi}$, by Proposition 2 .

Assuming that the cumulative distribution function $F(\alpha, \beta, \gamma)$ is continuous, the patent holder's excess reward function also is continuous in $r$. Therefore, by the intermediate value theorem, there must exist some $r^{*} \in[0, \max [\beta+\gamma]]$ such that the patent holder's excess reward is zero. Since the patent holder's expected payoff is monotonically increasing in $r, r^{*}$ will be unique. 
Proposition 4: If the Court is certain there are ex post gains from trade, then the optimal royalties are at least as large as the royalties in the Simple Royalties Regime, $r^{*} \geq r(a, b)$.

\section{Proof of Proposition 4}

$P$ 's benchmark expected payoff is $\bar{\Pi}=a+\theta \iint_{\beta>\alpha}(\beta-\alpha) g(\alpha, \beta) d \alpha d \beta \geq a$. Since there are ex post gains from trade and $P$ and $D$ bargain efficiently, $D$ will use the patented technology. If the Court sets the royalties at $r$, in state of nature $(\alpha, \beta, \gamma), D$ will pay royalties equal to $\min [r, \alpha+\theta(\beta+\gamma-\alpha)]$. This expression is monotonically non-decreasing in $r$, so the patent holder's expected payoff also is monotonically non-decreasing in $r$.

Suppose the Court sets the royalties at $r=r(a, b)$. If $a \geq b$, then $r(a, b)=a$, and in state of nature $(\alpha, \beta, \gamma), D$ will pay royalties of $\min [a, \alpha+\theta(\beta+\gamma-\alpha)]$. Since $P$ can get no more than $a$ in any state of nature, $P$ 's expected payoff is at most $a \leq \bar{\Pi}$. Since $P$ 's payoff is monotonically non-decreasing in $r$, this implies that $r^{*} \geq r(a, b)$. Alternatively, if $b>a$, then $r(a, b)=a+\theta(b-a)$. In that case, $\mathrm{D}$ will pay $\min [a+\theta(b-a), \alpha+\theta(\beta+\gamma-\alpha)]$. Since the patent holder can never get more than $a+\theta(b-a)$, P's expected payoff is at most $a+\theta(b-a) \leq a+\theta \iint_{\beta>\alpha}(\beta-\alpha) g(\alpha, \beta) d \alpha d \beta=\bar{\Pi}$. This implies that $r^{*} \geq r(a, b)$.

Proposition 5: If the Court is certain there were ex ante gains from trade and if $\min [\alpha+\theta(\beta+\gamma-\alpha)] \geq a+\theta(b-a)$, then the Optimal Royalties Regime coincides with the Simple Royalties Regime, so $r^{*}=a+\theta(b-a)$.

\section{Proof of Proposition 5}

In Licensing states of nature, the benchmark return to $P$ in state of nature $(\alpha, \beta)$ is equal to $\alpha+\theta(\beta-\alpha)$. If all states of nature are Licensing states, the benchmark expected return to $P$ is equal to $a+\theta(b-a)$. Suppose the Court sets $r=a+\theta(b-a)$. If the downstream firm would pay those royalties in each state of nature rather than negotiate a lower rate, then the patent holder's expected return will be equal to its benchmark level. The downstream firm will pay royalties $a+\theta(b-a)$ in state of nature $(\alpha, \beta, \gamma)$ rather than negotiate a lower rate if $a+\theta(b-a)<\alpha+\theta(\beta-\alpha)+\theta \gamma$. If $\min [\alpha+\theta(\beta-\alpha)+\theta \gamma] \geq a+\theta(b-a)$, this condition holds in all states of nature.

Proposition 6: If the Court is certain there are ex post gains from trade, but uncertain there were ex ante gains from trade, then the Simple Royalties Regime strictly under-rewards the patent holder.

\section{Proof of Proposition 6}

$P$ 's benchmark expected payoff is $\bar{\Pi}=a+\theta \iint_{\beta>\alpha}(\beta-\alpha) g(\alpha, \beta) d \alpha d \beta$. Since Licensing states of nature occur with positive probability, $\bar{\Pi}>a$. Since Lock-In states of nature occur with positive probability, $\bar{\Pi}>a+\theta(b-a)$. Therefore, $\bar{\Pi}>\max [a, a+\theta(b-a)]=r(a, b)$. Since $r(a, b)$ is an upper bound for the patent holder's return in any state of nature under the Simple Licensing Regime, this implies that the Simple Royalties Regime strictly under-rewards the patent holder. 
Proposition 7: The Simple Royalties Regime performs better than the Injunction Regime if the switching costs are large in the sense that (a) $\operatorname{Prob}[\gamma>|\beta-\alpha|]=1$, and

(b) $\theta * \min [\gamma]>\boldsymbol{r}(\boldsymbol{a}, \boldsymbol{b})-\min [\alpha+\theta(\beta-\alpha)]$.

\section{Proof of Proposition 7:}

Since $\beta+\gamma>\alpha$ in all states of nature, there are no Redesign states of nature. Therefore, the presence of absence of antitrust limits in Redesign states of nature makes no difference. The only states of nature that arise are Licensing and Lock-In states.

Under the Simple Royalties Regime, the court-awarded royalties are given by $r(a, b)$. As shown in Figure 2, in Licensing and Lock-In states of nature the downstream firm will pay the courtawarded royalties $r$ if $r<(1-\theta) \alpha+\theta \beta+\theta \gamma$. With $r=r(a, b)$ this condition becomes $r(a, b)<(1-\theta) \alpha+\theta \beta+\theta \gamma$. This inequality is satisfied in all states of nature if $\theta * \min [\gamma]>r(a, b)-\min [\alpha+\theta(\beta-\alpha)]$, in which case the patent holder's expected payoff under the Simple Royalties Regime is equal to $r(a, b)$.

The patent holder's benchmark expected payoff is given by $\bar{\Pi}=a+\theta \Delta$. If $b>a$, then $r(a, b)=a+\theta(b-a)$ and the patent holder's shortfall under the Simple Royalties Regime is equal to $\bar{\Pi}-r(a, b)=\theta \Delta-\theta(b-a)$. Alternatively, if $a>b$, then $r(a, b)=a$ and the $P$ 's shortfall equals $\bar{\Pi}-a=\theta \Delta$. In either case, the shortfall is no larger than $\theta \Delta$, which can be written as $\theta * \operatorname{Prob}$ [Licensing $] * E[(\beta-\alpha) \mid$ Licensing]. Since $\gamma>\beta-\alpha$ in all states of nature, the patent holder's shortfall under the Simple Royalties Regime is less than $\theta * \operatorname{Prob}[$ Licensing $] * E[\gamma \mid$ Licensing $]$.

Under the Injunction Regime, the patent holder's expected over-reward associated with Licensing states of nature is equal to $\theta * \operatorname{Prob}[$ Licensing $] * E[\gamma \mid$ Licensing $]$. The patent holder's payoff is at least as large as the benchmark level in Lock-In states of nature. Therefore, the patent holder's expected over-reward under the Injunction Regime is at least as large as $\theta * \operatorname{Prob}[$ Licensing $] * E[\gamma \mid$ Licensing $]$.

Proposition 8: If the downstream firm does not compete against the patent holder or its licensees, then the Simple Royalties Regime, $r=\theta b$, gives the benchmark expected payoff to the patent holder if the Court is certain that $D$ 's ex post willingness to pay for the patented technology exceeds the expected ex ante value of the patented technology, i.e., if $\min [\beta+\gamma]>b$.

\section{Proof of Proposition 8}

The Simple Royalties Regime with royalties $r=\theta b$ gives the patent holder a payoff in state of nature $[\beta, \gamma]$ equal to lesser of $\theta b$ and $\theta(\beta+\gamma)$. The expected payoff from the Simple Royalties Regime is generally less than the benchmark level $\theta b$ because $D$ negotiates lower royalties of $\theta(\beta+\gamma)$ when $\beta+\gamma<b$. However, if $\min [\beta+\gamma]>b$, this never happens, so the Simple Royalties Regime gives the patent holder its benchmark expected return of $\theta b$. 
Proposition 9: If the downstream firm competes against the patent holder's licensees and $\alpha=\delta \beta$, then the Simple Royalties Regime gives the benchmark expected payoff to the patent holder if $\theta * \min [\gamma]>(\theta+\delta(1-\theta))(b-\min [\beta])$.

\section{Proof of Proposition 9}

The royalty regime with royalties $r$ gives the patent holder a payoff in state of nature $[\beta, \gamma]$ equal to lesser of $r$ and $(\theta+\delta(1-\theta)) \beta+\theta \gamma$. With royalties $r=(\theta+\delta(1-\theta)) b$, this becomes the lesser of $(\theta+\delta(1-\theta)) b$ and $(\theta+\delta(1-\theta)) \beta+\theta \gamma$. If the first of these expressions is always less than the second, the royalty regime gives the patent holder its benchmark expected return. A sufficient condition for this to be the case is that $\theta \gamma>(\theta+\delta(1-\theta))(b-\beta)$ in every state of nature $[\beta, \gamma]$, i.e., that $\theta * \min [\gamma]>(\theta+\delta(1-\theta))(b-\min [\beta])$.

\section{Simulation Results}

We now report our simulation results comparing the Injunction Regime and the Simple Royalties Regime and calculating $r^{*} / r(a, b)$. We assume the two parties have equal bargaining skill, so $\theta=0.5$. We assume that the switching cost $\gamma$ is known. We perform comparative statics on $\gamma$. All of these simulations were performed using Mathematica.

\section{Normal Distribution}

We begin by reporting simulations in which $(\alpha, \beta)$ is normally distributed. We assume that $\alpha$ and $\beta$ have the same standard deviation, $\sigma$, and a correlation coefficient of $\lambda=0.5$. Positive correlation would arise, for example, if $\alpha$ and $\beta$ both depend on the future significance of the patented technology or on the future growth of demand for both firms' products. In particular, in situations where the two firms compete significantly against each other, if the Court underestimates the value to $D$ of including the patented feature in its product, or the growth of demand, then the Court may well also underestimate the harm to $P$ caused by $D$ 's infringement.

\section{Optimal Royalty Rate}

If $a=b$, meaning that the average harm to the patent holder from infringement equals the average benefit to the downstream firm, and if the switching cost $\gamma$ is equal to the standard deviation $\sigma$, then the ratio of the optimal royalty rate to the simple royalty rate $r^{*} / r(a, b)$ is 1.05 Higher switching costs cause the optimal royalty rate to be lower, but this ratio does not vary much with the switching cost: if $\gamma=2 \sigma$, then $r^{*} / r(a, b)=1.03$, and conversely if $\gamma=0.5 \sigma$, then $r^{*} / r(a, b)=1.08$. If $\gamma=0.01 \sigma$, then $r^{*} / r(a, b)=1.20$.

Imposing antitrust limits on reverse payments makes the ongoing royalties regime perform less well at any given court-awarded royalty rate and causes the optimal royalty rate $r^{*}$ to be slightly higher. In our base case with $a=b$ and $\gamma=\sigma$, imposing antitrust limits raises the ratio $r^{*} / r(a, b)$ very little, only from 1.0495 to 1.0525 .

Setting $a>b$, so the average harm to the patent holder from infringement exceeds the average benefit to the downstream firm, makes Licensing states of nature less likely and Redesign states of nature more likely. But this makes little difference for the ratio $r^{*} / r(a, b)$. In our base case with $\gamma=\sigma$, if $a=b+\sigma$, then $r^{*} / r(a, b)=1.039$, compared with $r^{*} / r(a, b)=1.050$ when $a=b$. If $a=b+2 \sigma$, then $r^{*} / r(a, b)=1.038$. Conversely, if $b>a$, Licensing states of 
nature become more likely, Redesign states of nature become less likely. If $b=a+\sigma$ then $r^{*} / r(a, b)=1.028$, and if $b=a+2 \sigma$ then $r^{*} / r(a, b)=1.021$.

Imposing antitrust limits on reverse payments makes the royalties regime provide a somewhat smaller expected payoff to the patent holder at any given level of $r$. Therefore, the optimal royalty level is higher with antitrust limits than without. In our base case where $a=b$ and $\gamma=\sigma$, these antitrust limits raise $r^{*} / r(a, b)$ from 1.050 to 1.053 .

\section{Simple Royalties Regime vs. Injunction Regime}

In these simulations, the patent holder's over-payment under the Injunction Regime grows with the switching cost $\gamma$, while the patent holder's under-payment from the Simple Royalties Regime declines with $\gamma$. (This happens because the value of the downstream firm's option to negotiate rather than pay the court-awarded royalties declines as the switching costs grow). As a result, there is a critical value $\gamma^{*}$ such that the Injunction Regime is superior to the Simple Royalties Regime if and only if $\gamma<\gamma^{*}$.

In our base case, where $a=b, \gamma^{*} \approx 0.92 * \sigma$. In other words, if the switching costs are more than the standard deviation with which the Court estimates the benefits and costs of patent infringement, the Simple Royalties Regime performs better than the Injunction Regime. If $a=b+\sigma$, then $\gamma^{*} \approx 1.03 * \sigma$, so somewhat larger switching costs are necessary for the Simple Royalties Regime to perform better than the Injunction Regime. Likewise, if $a=b+2 \sigma, \gamma^{*} \approx 1.59 * \sigma$. Moving in the other direction, if $b=a+\sigma$, then $\gamma^{*} \approx 0.56 * \sigma$, and if $b=a+2 \sigma$ then $\gamma^{*} \approx 0.49 * \sigma$.

Imposing an antitrust limit on reverse payments makes the Simple Royalties Regime perform somewhat worse, which slightly raises $\gamma^{*}$. In our base case where $a=b$, we now get $\gamma^{*} \approx 0.97 * \sigma$, compared to $\gamma^{*} \approx 0.92 * \sigma$ from just above.

\section{Pareto Distribution}

We have also run simulations using the Pareto distribution to see how our results change if we use a distribution with a fatter tail. The Pareto distribution with parameters $[k, \varepsilon]$ for $k>0$ and $\varepsilon>2$ has a density function $\varepsilon k^{\alpha} x^{-1-\varepsilon}$ for $x \geq k$, with mean $k \varepsilon /(\varepsilon-1)$ and variance $\varepsilon k^{2} /(\varepsilon-2)(\varepsilon-1)^{2}$. In our base case, $\alpha$ and $\beta$ each follow a Pareto distribution with parameters $[10,4]$. With these parameters, the minimum value of the patented technology is 10 , the mean value is 13.3, and the standard deviation is about 4.7. With these parameters, the Injunction Regime performs better than the Simple Royalties Regime if and only if the switching cost is less than 2.0, which means that $\gamma^{*} \approx 0.42 * \sigma$. We again find that if the switching cost is less than the standard deviation by which the court measures the value of the patented technology, the Simple Royalties Regime performs better than the Injunction Regime.

We also have calculated the ratio $r^{*} / r(a, b)$ in our simulations using the Pareto distribution. In the base case just described, with switching costs $\gamma=5$, chosen to be comparable to the standard deviation of $\alpha$ and $\beta$, we find that $r^{*} / r(a, b)=1.07$. This too is similar to what we found using the normal distribution. Using the Pareto distribution with parameters [10,3], which gives a fatter tail, with a mean of 15 and a standard deviation of 8.7, we get $r^{*} / r(a, b)=1.11$. 